\title{
Yerli Yapım Çizgi Filmlerde Toplumsal Cinsiyet Eşit(siz)liği ${ }^{1}$
}

DOI: $10.26466 /$ opus. 910874

\author{
* \\ Ayşegül Deniz* \\ * Arş. Gör. Dr, Hacettepe Üniversitesi, Eğitim Fakültesi, Ankara/Türkiye \\ E-Posta: ayseguldeniz@hacettepe.edu.tr \\ ORCID: $0000-0003-0644-2902$
}

\begin{abstract}
Öz
Bu araştırmada tematik çocuk kanallarında yayınlanan yerli yapım çizgi filmlerin toplumsal cinsiyet eşitliğ̈i açısından incelenmesi amaçlanmıştır. Bu kapsamda Biz İkimiz, Canım Kardeşim, Kral Şakir ve Neşeli Dünyam çizgi filmlerine ait toplam 83 bölüm nitel araştırma tekniklerinden içerik analizi tekni ğiyle değerlendirilmiştir. Anne, baba, klz ve oğlan çocuk karakterleri kamusal alanda bulunma, gündelik yaşam etkinlikleri, davranış özellikleri altında toplumsal cinsiyet eşitliği açısından incelenmiş; anne ve baba karakterleri için çocuklarıyla kurdukları iletişim ayrı bir kategori olarak analiz edilmiştir. Sonuç olarak anne karakterlerin baba karakterlere göre daha az kamusal alanda bulundukları, yemek, ev ve çocuk bakım işlerinde yoğunlaştıkları, duygusal ve domestik olma özellikleri ile temsil edildikleri görülmüştür. Baba karakterlerin kamusal alanda daha fazla yer aldıkları, tamir işleri, ulaşım aracı kullanma, işe gidip işten gelme etkinliklerini gerçekleştirdikleri, bilim ve teknoloji ile ilgili olma ve kendine güvenme davranış özellikleri ile ön plana çıtıkları görülmüştür. Babalar günümüzde değişen babalık rollerine uygun olarak çocuklar ile iletişimlerinde arkadaş gibi olma özellï̆ine sahipken; annelerin daha ciddi ve öğretici bir iletişim içinde oldukları saptanmıştır. Kız ve oğlan çocuk karakterlerinin de anne ve baba karakterlerinin eylemleri ve davranış özellikleri ile benzer şekilde temsil edildikleri ortaya çıkmıştır. Kız çocukları gündelik yaşam etkinliklerinde en çok ev işlerine yardım etme, oğlan çocuklar ise tamir etme eylemi ile ilişkilendirilmiştir. Kız çocukları dış görünüşe ve güzelliğe önem verirken, oğlan çocuklar bilim ve teknoloji ile ilgili karakterler olarak temsil edilmektedir. Yerli yapım çizgi filmlerde toplumsal cinsiyet kalip yargılarının yeniden üretildiği ortaya koyulmuştur. Bu durum çizgi film izleyicisi çocukların cinsiyete dair kalıp yargıları çizgi filmler aracılı̆̆ıyla pekiştirmeleri ve üzerinden yorumlanmıştır.
\end{abstract}

Anahtar Kelimeler: Toplumsal Cinsiyet Rolleri, Toplumsal Cinsiyet Kalıp Yargıları, Feminizm, Medya, Çocuk.

\footnotetext{
${ }^{1}$ Bu çalışma Hacettepe Üniversitesi Sosyal Bilimler Enstitüsü Kadın ve Toplumsal Cinsiyet Çalışmaları Programında tamamlanan Yerli Yapım Çizgi Filmlerde Toplumsal Cinsiyet Eşit(siz)liği başıklı yüksek lisans tezinden üretilmiştir.
} 


\title{
Gender (In)Equality in Turkish Cartoon Series
}

\begin{abstract}
This research aims to examine the Turkish cartoon series broadcasted on thematic children's channels in terms of gender equality. In this context, a total of 83 episodes of Biz İkimiz, Canım Kardeşim, Kral Şakir, and Neşeli Dünyam were evaluated using content analysis technique, one of the qualitative research techniques. Mother, father, girl, and boy characters were examined in terms of gender equality under the categories of being in the public space, daily life activities, and behavioral characteristics. Communication with their children was analyzed as a separate category for the mother and father characters. As a result, it was observed that the mother characters were less in the public sphere than the father characters, concentrated on cooking, house works, and baby care, and represented with the characteristics of being emotional and domestic. It was observed that the father characters were more involved in the public sphere, perform daily activities such as repairing, driving, and going to work, is related to science and technology, and being self-confident. While fathers have the feature of being like friends in their communication with their children in line with their changing fatherhood roles; it was found that mothers had more serious and instructive communication. It has been revealed that the girl and boy characters are represented similarly with the daily activities and behavioral characteristics of the mother and father characters. Girls were most associated with helping house works in daily life activities, while boys were associated with repairing. While girls value looks and beauty, boys are represented as characters related to science and technology. It has been revealed that gender stereotypes are reproduced in Turkish cartoons. These results show that gender stereotypes are reinforced in cartoons. This situation has been interpreted as children's reinforcing stereotypes about gender through cartoons.
\end{abstract}

Keywords: Gender Roles, Gender Stereotypes, Feminism, Media, Child. 


\section{Giriş}

Toplumsal cinsiyet, toplumun kadından ve erkekten beklediği, cinsiyetlere yüklediği davranışları anlatmak için kullanılan bir kavram olup cinsiyetin kişilik özelliklerinin ötesinde, toplumsal yapı ve ilişkilerle bağlantılı öznel boyutunu ifade etmektedir. Erkeklik (erillik) ve kadınlık (dişilik) durumunun toplumda nasıl inşa edildiği ve cinsiyetler arasındaki farkl1lığın nasıl ortaya çıktığı toplumsal cinsiyet kavramıyla açılanmaktadır. "Cinsiyet" kavramı biyolojik olarak erkek kadın ayrımını anlatırken, "Toplumsal cinsiyet" kavramı ile erkeklik ve kadınlık arasındaki farklılıkların toplumsal olarak inşa edildiğine, toplumsal bakımdan eşitsiz bölünmeye gönderme yapılmaktadır (Baştürk Akca ve Ergül, 2015, s.17; Bora ve Üstün, 2008, s.41; Görgün Baran, 2012, s.410; Oakley, 2016, s.5).

Toplumsal cinsiyetin kuramsal olarak kullanılması kadın erkek ikiliği çerçevesinde yer almaktadır (Karkıner, 2015, s. 58). Ataerkil toplumlarda, toplumsal cinsiyet özellikleri olarak kadınlardan duygusal, sezgisel, hassas, çekingen, şefkatli, itaatkâr, bağımlı, iyi huylu, destekleyici, düzenli, çekici, fedakâr, kibar, anlayışlı, pasif ve sabırlı olup özel alanda olmaları beklenirken; erkeklerden akıllı, cesur, kavgacı, dayanıklı, mücadeleci, güçlü, bağımsız, girişken, otoriter, sert, sorumluluk sahibi, başarılı, hırslı olmaları ve kamusal alanda yer almaları beklenmektedir (Atkinson, Atkinson ve Hilgard, 2012; Zastrow ve Krist Ashman, 2014). Biyolojik cinsiyetlerinin ötesinde kadınlardan ve erkeklerden farklı rolleri üstlenmelerini beklemek kadınların ve erkeklerin farklı ilgilerinin olmasına, farklı uzmanlık alanları geliştirmelerine ve gündelik hayatlarında farklı etkinlikler geçirmelerine neden olmaktadır (Taylor, Peplau ve Sears, 2015).

Connell (1987) her toplumda toplumsal cinsiyet farkl1lılarının bir dizi erillik ve dişillik özelliklerinden ortaya çıktığını ve bunların yeniden üretildiğini belirtmekte; toplumsal cinsiyetin, erilleri ve dişileri belli toplumsal bağlamlarda birleştiren toplumsal, kültürel ve psikolojik özellikleri kapsamakta olduğunu vurgulamaktadır (Akt: Lindsey, 2011, s.4). Feminist bakış açısı ile cinsiyete ilişkin özelliklerin kadın-erkek, kamusal-özel, geleneksel-modern gibi ikili karşıtlıklar üzerinden kurulması üzerine eleştiri getirilmektedir. Eril özelliklerin dişil özelliklerden üstün görüldüğüne, eril ve dişil arasında bir hiyerarşi oluşturulduğuna ve bu hiyerarşi- 
nin eril iktidarı yeniden üretip pekiştirerek eşitsizliğe neden olduğuna işaret edilmektedir. (Kurdoğlu, 2011, s.109). Hiyerarşik ve bir tahakküm mantığ 1 üzerinden işlemekte olan bu özelliklerin zihin/beden, akıl/duygular, us/usdışı, uygarlık/doğa, özne/nesne ikilikleri gibi düalizm içermekte olduğuna dikkat çekilmektedir. Bu değerlerden birinciler erilliğe, ikinciler dişiliğe atfedilmektedir. Böylece kadınların, eril değerlerle özdeşleştirilen otorite, kamusal alan, iktidar, politik temsil gibi kavramlardan ve kurumlardan dişlanmakta olduğu sonucuna ulaşılmaktadır (Alkan, 2000, s.73).

Gölgelioğlu (2011, s.65), kamusal alanın yasaların yapıldığı, politikanın tartışıldığı ve kararlaştırıldığı, vatandaşların siyasete dâhil olduğu bir alan olarak tanımlandığını; özel alanın ise aile ve hane içi alan ile ilgili olup günlük ihtiyaçların karşılandığı bir alan olduğunu belirtmektedir. Bu durumda ailenin reisi olan erkeğin kamusal alanda politika ve siyasete katılımı söz konusuyken, kadınların ev içinde günlük yaşamsal ihtiyaçlar çerçevesinde çocuk bakımı, yemek, temizlik gibi işlerle uğraştığına vurgu yapmaktadır. Donovan (2020, s.17-20), toplumsal cinsiyeti merkeze alan çalışmalarda, kadınların özdeşleştirildiği özel alandan farklı olarak, kamusal alanın iktidar kullanımına ait olan akılcılığın mekânı olarak kabul edildiğini belirtmektedir. Feministler, özel alana ait mahremiyet kavram1nın şiddet, istismar ve sömürünün ortaya çımasına engel olduğunu ve modern hane halkının evcillik ve annelik ideolojileri sayesinde sürekli bir kadın emeğine dayandığını vurgulamaktadır (Bilton ve diğ., 2009, s.39). Saldırganlık, girişkenlik gibi özellikler genellikle erkeklere atfedilmekte ve bu özellikler kamusal alanı içeren iş dünyası ve politika hayatında etkin hale gelmelerini sağlamaktadır. Kadına atfedilen uysal, edilgen ve bağımlı olunmasına dair özellikler ise kadını özel alana yerleştirmekte, çocuk bakımı ve yetiştiricilik rollerini üstlenmesine neden olduğu şeklinde değerlendirilmektedir (Günindi Ersöz, 2015, s.82).

Cinsiyete dayalı iş bölümü ailede başlamakta, görevler toplumsal cinsiyet rolleri özelliklerine göre dağıtılmaktadır. Ailede yetişkinlerden biri dışarıda çalışırken, diğeri evin ve çocukların bakımını üstlenmektedir. Bu durumda erkek evin geçimini sağlayan kişi olmakta ve kadın da ev ortaminda sevecen ve duygusal rolü üstlenmektedir (Giddens, 2012, s.187). Kadınlar bir meslek sahibi olsalar da asıl işlerinin evle ilgili sorumluluklar olduğu kabul edilmekte; ev içi işler ve bakım işleri çok fazla emek gerek- 
tirse de bu işler görünür ve karşıllı̆̆ olan işler olarak değerlendirilmemektedir (Bora, 2011, s.6). Kadınların, ev işlerinin karşılıksız bir emek harcama biçimi olduğunu açı̆ga çıkarıp bunu politik bir sorun olarak gündeme getirmelerinin önündeki başlıca engellerden biri, bu işlerin bir sevgi ilişkisi içinde görülüyor olması olarak yorumlanmaktadır (Acar Savran, 2019, s.19).

Aile, toplum ile doğrudan ilişkili ve sosyalleşmenin en önemli sağlayıcısı olup aile değerlerinin kişinin günlük davranışlarıyla doğrudan ilişkili olduğu görülmektedir (Gürsoy, 2012, s.203). Anne, baba ve çocuklardan oluşan modern aile kurumunun günümüzdeki işlevlerinden birisi, çocukların sosyalleşmesinden ve gelişiminden sorumlu olması çerçevesinde nitelendirilmektedir (Bahar, 2015, s.227). Geçmişte ve günümüzde çocuk bakımında en fazla sorumluluk alan kişiler anneler olup annelik çocukların yalnızca fiziksel bakımını değil, psikolojik, sosyal ve entelektüel gelişiminden sorumlu olmayı da gerektirmektedir (Bilton ve diğ., 2009, s.146). Chodorow (1978) anne olarak kadınların sosyal yeniden üretim alanında önemli aktörler olduğunu ve cinsiyete dayalı iş bölümünün temelini kadınların annelik rolünün oluşturduğunu savunmaktadır. Cinsiyetlere dair kalıp yargıların aile içinde oluştuğunu ve bunun nedenin de cinsiyete dayalı iş bölümü olduğunu iddia etmektedir.

Giddens (2020, s.115), günümüzde varlığını sürdüren aile kurumunun temeli olan çekirdek ailede, ebeveynler ile çocuklar arasındaki ilişkilerin daha duygusal bir içeriğe sahip olduğunu belirtmektedir. Günümüzde babalardan, çocukların korku duydukları otoriter özelliklerinden öte çocuklarıyla arkadaş, çocukla zaman geçiren ve oyun oynayan, çocuğa bir şeyler öğreten ve yol gösteren ve çocuğun eğitip kendisine model olarak alabileceği ebeveynler olmaları beklenmektedir (Tezel Şahin, 2007, s.771). Ancak bu durumun yüzeysel olduğu, babaların çocuklarına daha arkadaşça davransalar da çocuklarla geçirdikleri zamanın oyun oynamakla s1nırlı kaldığ 1 ve bebek bakımı işlerinin anneye ait olarak devam ettiği görülmektedir (Çabuklu, 2007, s.105). Küreselleşen dünyada günümüz toplumları diğer kültürlerin etkilerine daha açık bir hale gelmekte ve bu bağlamda geleneksel, kültürel inanç ve değerlerle temellenmiş olan annelikbabalık uygulamaları ile modern annelik-babalık uygulamaları iç içe geçmektedir (Sayıl ve Yağmurlu, 2012, s.15-16). İçin Akçalı (2020), klasik ataerkil aile yapısının anne, baba ve çocuk ilişkisinde iktidar, işbölümü ve 
toplumla kurulan bağ açısından değiştiği bir dönemden geçildiğini belirtmektedir. Günümüz toplumu aile yapılanmasında medyanın önemli bir araç olduğuna dikkat çekmekte ve ataerkil aile yapısının 'medyaerkil' bir aile yapısına dönüştüğü yorumunu getirmektedir.

\section{Medya ve Toplumsal Cinsiyet}

Medya sosyalleşme araçlarından birisi olup toplumun kültürel ve sosyal yapısının belirlenmesinde ve toplumsal yargiların olumlu ya da olumsuz yönde değişmesinde önemli rol oynamaktadır. Medya aracılığıyla oluşturulan popüler kültürün bu etkisi, aile içi ilişkilerde, cinsiyet rollerinde ve otorite figürlerinde önemli değişiklere yol açmaktadır (Adaçay, 2018, s.253). Toplumsal cinsiyet kavramı 1970’lerden günümüze aile, politika, gündelik yaşam, ekonomik kalkınma, hukuk, eğitim gibi pek çok alanda analizlere dâhil edilmektedir (Browne, 2014). Çocukların toplumsal cinsiyet rollerini öğrenmesinde aileleri kadar etkili olan ve toplumsal cinsiyet eşitsizliğinin yeniden üretilmesinde temel araçlardan biri olarak değerlendirilen medya da bu analizlere dâhildir (Ward ve Grower, 2020).

Althusser'e göre bir ideolojik aygıt olarak kitle iletişim araçları hem egemen ideolojiyi aktarmakta hem de yeri geldiğinde gerekli düzenlemeleri ve düzeltmeleri yaparak bireylerin topluma uyumları sağlanmaktadır (Akt: Güler, 2014, s.6027). Toplumsal cinsiyetin inşa edilmesi ve sürdürülmesi süreci de bu kapsamda değerlendirilmektedir (Görgün Baran, Sarıtaş Eldem ve Şahin Kütük, 2017).

Televizyonun artık her eve girmiş olması, kanal sayılarının artması, evde birden fazla televizyon olması ve yaygınlaşan çocuk programları nedeniyle çocuk ve televizyon arasında kuvvetli bir bağ kurulmaktadır (Işık, Erdem, Güllüoğlu ve Akbaba, 2007, s.95). Sosyal Öğrenme Kuramı televizyon ve diğer görsel-işitsel teknolojileri özellikle de gerçek dünyaya ait birçok şeyi medya araçları aracılığıyla öğrenen çocuklar açısından önemli gözlemsel öğrenme kaynakları olarak görmektedir (Laughey, 2010, s.44).

0-8 yaşları içine alan erken çocukluk dönemi gelişimin en hızlı olduğu dönemdir ve televizyon bu dönemde görselliğe hitap ederek çocukların dikkatini çeken bir uyarıcı olarak karşımıza çıkmaktadır (Atay ve Çelebi Öncü, 2020, s.69). Çocuklar çok küçük yaşlardan itibaren televizyon izlemeye başlamakta ve erken çocukluk dönemindeki çocuklar televizyon 
karşısında ortalama 2 saat geçirmektedir (Akkuş, Yılmazer, Şahinöz ve Sucaklı, 2015; Öztürk ve Karayağız, 2007). Çocukların en fazla izledikleri programlar da çizgi filmler olmaktadır (Cesur ve Paker, 2007; Yazıcı, Yaman Baydar ve Kandır, 2019). Televizyonun yanı sıra cep telefonu, tablet, bilgisayar gibi teknolojik aletler de çocukların iletişim, eğlence ve öğrenmelerinde etkili olmakta ve çocuklar bu araçlardan da çizgi filmleri izlemektedir (Aral ve Doğan Keskin, 2018). Cinsiyet Şeması Kuramı, çocukların ebeveynlerden, öğretmenlerden ve medyadan cinsiyet kategorileri ve rolleri hakkında önemli bilgiler aldıklarını vurgulamaktadır (Bem, 1983). Gelişim ve öğrenme açısından kritik olan erken çocukluk döneminde çocukların izlediği çizgi filmlerin içerikleri bu anlamda önem taşımaktadır.

\section{Çizgi Filmler ve Toplumsal Cinsiyet}

Çizgi filmler çocukların görsel, işitsel, duyularına hitap etmekle birlikte çocukların sosyal, duygusal, dil ve bilişsel gelişim alanları üzerinde de son derece etkilidir. Giroux (1983), çizgi filmlerin sosyal değerleri öğretmede aile, okul ve din kurumlarından bile daha etkili olduğunu belirtmektedir. Çizgi filmlerde yer alan karakterler izleyici için birer model olmakta ve simgesel tasarımlar, bilimsel süreçler, akıl yürütme ve problem çözme ya da dünyayı tanıma yoluyla alternatif eğitim yaşantıları gösterilmektedir. Çizgi filmlerin günlük ilişkilerdeki temel şablon ve insan prototiplerini izleyiciye sunarak, insan ilişkilerinin devamını mümkün kılan duygulara, değer yönelimlerine ve davranışlara da sıklıkla yer verdikleri de görülmektedir (Özgökbel Bilis, 2011).

Çocuklara yönelik çizgi filmler pek çok araştırmaya konu olmakta ve toplumsal cinsiyet açısından incelenmektedir. Televizyonda erkek karakterlerin yoğun olduğu programların ortak özelliklerinin güç odaklı olduğu görülmektedir (Chu ve McIntyre, 2009; Thompson ve Zerbinos, 1995). Çizgi filmlerde erkekler daha çarpıcı ve baskın olarak canlandırılmakta ve diyalogların çoğunu gerçekleştirmekte ve önemli etkinlikleri yürütürken temsil edilmektedir (Barner, 1999). Güçlü erkek ana karakterler ve onların etrafındaki yan karakterlerin öykülerinden oluşan içerikler mevcuttur (Götz ve diğ., 2008; Ogletree ve diğ., 2004). Kız çocuklarına yönelik hazırlanan programların daha çok duygulara seslenen, kıyafet, saç, 
makyaj gibi dış görünüşün ön plana çıtığı içeriklerle dolu olduğu görülmektedir (Işık, Erdem, Güllüoğlu ve Akbaba, 2007, s.97; Taylor, Peplau ve Sears, 2015, s.346). Türkiye' de çocuk programcılığında cinsiyetçi bakış açısının yeniden üretildiği, kadın erkek eşitliğinin yeterince işlenmediği ve erkek egemen kültür çocuklara aşılandığı belirtilmektedir (Şirin, Oktay ve Altun, 2013).

Birçok araştırmada, çocuklara yönelik yayınlarda kadınların erkeklerden daha az yer aldıkları (Calvert, Kotler ve Zehnder, 2003; Edwin ve diğ., 2012), düşük statülü bir işe sahip olarak temsil edildikleri (Eick, 1998), kadınların erkek karakterlerden daha az bilgili kişiler olarak ikinci planda gösterildikleri (Thompson ve Zebrinos, 1995) ve toplumsal cinsiyet rolleriyle ilgili olarak kalıp yargıların yeniden üretildiği ortaya koyulmuştur (Barner, 1999; Calvert, 1999; Kalayc1, 2015, Ogletree ve diğ., 2004).

Yapılan araştırmalar, medya ürünlerinde inşa edilen toplumsal cinsiyetin çocukların cinsiyet şemalarına dâhil edildiğine ve çocukların cinsiyete ilişkin inanç ve davranışları ile kendi cinsiyet tipindeki davranışlarını şekillendirmekte olduğuna işaret etmektedir (Coyne, Linder, Rasmussen, Nelson ve Birkbeck, 2016; Coyne, Linder, Rasmussen, Nelson ve Collier, 2014; Martin, Ruble ve Szkrybalo, 2002; Ward ve Grower, 2020). Kalıp yargılarla dolu çizgi filmleri izledikçe, çocukların cinsiyete dair kalıp yarg1ları daha çok pekiştirdikleri ve davranışlarına yansıttıkları görülmektedir (Ahmed ve Wahab, 2014; Zaheen ve Khan, 2019).

Son zamanlarda ülkemizde hem tematik çocuk kanallarının sayısında hem de yerli yapım çizgi filmlerin sayısında artış olduğu görülmektedir. 2021 yılı itibariyle ülkemizde şifreli ve şifresiz yayın yapan toplamda 14 tematik çocuk kanalı bulunmaktadır. Bunlardan TRT Çocuk şifresiz, diğer çocuk kanalları ise şifreli yayın yapmaktadır. Toplumsal cinsiyet ile ilgili kavramlar ve yaşantılar da çizgi filmlerde yer almaktadır. Bu bağlamda cinsiyet ile ilgili rollerin toplumsal olarak inşa edildiği görüşü çerçevesinde bu temalara çizgi filmlerde nasıl yer verildiğinin incelenmesi önemli bir konu haline gelmektedir.

\section{Araştırmanın Amacı ve Önemi}

$\mathrm{Bu}$ araştırmada, cinsiyetlere dair kalıp yargıların aile ilişkilerinde ve aile içi iş bölümünde yer almasından hareketle, Türkiye'de ulusal ve kablolu 
yayın yapan tematik çocuk kanallarında yayınlanan ve karakterleri anne, baba, çocuk gibi aile üyelerinden oluşan erken çocukluk dönemindeki çocuklara yönelik hazırlanmış olan aile odaklı yerli yapım çizgi filmlerin toplumsal cinsiyet eşitliği açısından incelenmesi amaçlanmıştır. Bu amaç kapsamında TRT Çocuk Kanalı'ndaki Canım Kardeşim ve Biz İkimiz; Minika Çocuk Kanalı'nda Neşeli Dünyam; Cartoon Network Kanalı'nda Kral Şakir çizgi filmlerinin bölümleri incelenmiştir.

RTÜK 2016-2020 Stratejik Planı'nda yayınlarda yerli yapımlara yer verme zorunluluğu getirilmektedir. Çocuklara yönelik çizgi filmlerin en az \%20'sinin Türkçe dilinde üretilmiş yapım olması ve Türk kültürünü yansıtması gerektiği belirtilmektedir (RTÜK, 2016). Yerli kültüre bu kadar önem verilmesi geleneksel öğelerin ön plana çımasına neden olabilmektedir. Yerli kültürün aktarıcısı olarak görülen ve son zamanlarda sayıca artan yerli yapım çizgi filmlerin toplumsal cinsiyet eşitliği açısından değerlendirilmesinin önemli olduğu düşünülmektedir. Yerli yapım çizgi filmlerde toplumsal cinsiyet eşitliğinin incelendiği çalışmaların daha çok TRT Çocuk kanalında yayınlanan çizgi filmlere yönelik olduğu görülmektedir (Kalaycı, 2015; Keloğlu İşler, 2014; Muratoğlu Pehlivan, 2019; Özen Uyar ve Y1lmaz Genç, 2017; Özsoy ve Taşdelen; Saraç, 2018; Şen, 2020; Ünlü, 2017; Yağan Güder, Ay, Saray ve Kılıç, 2017). Bu çalışmada TRT Çocuk ile diğer kanallardaki çizgi filmlerin de incelenmesi amaçlanmış ve dört ayrı çizgi filme yer verilmiştir.

Araştırmanın temel problemini; aile üyelerinin yer aldığı yerli yapım çizgi filmlerde anne (kadın), baba (erkek) ve kız çocuk, oğlan çocuk karakterlerine ait eylemlerin ve özelliklerin toplumsal cinsiyet eşitliği açısından nasıl temsil edildiği oluşturmaktadır. Bu çalışmada toplumsal cinsiyet eşitliği kapsamında aşağıdaki sorulara cevap aranmışır:

1. Ana karakterlerin ve yan karakterlerin cinsiyete göre dağılımı nasıldir?

2. Anne ve baba karakterlerinin kamusal alanda bulunma durumları nasıldir?

3. Anne ve baba karakterleri hangi günlük yaşam eylemlerini hangi düzeyde gerçekleştirmektedir?

4. Anne ve baba karakterleri hangi davranış özelliklerine hangi düzeyde sahiptir? 
5. Anne ve baba karakterleri çocuklarıyla iletişimlerinde hangi özellikleri hangi düzeyde üstlenmektedir?

6. Kız ve oğlan çocuklarının kamusal alanda bulunma durumları nasıldir?

7. Kız çocukları ve oğlan çocukları hangi günlük yaşam eylemlerini hangi düzeyde gerçekleştirmektedir?

8. Kız ve oğlan çocukları hangi davranış özelliklerine hangi düzeyde sahiptir?

\section{Yöntem}

$\mathrm{Bu}$ araştırma, aile (anne, baba ve çocuk) karakterlerine yer verilen yerli yapım çizgi filmlerde yer alan diyalogların ve eylemlerin toplumsal cinsiyet açısından derinlemesine incelenmesini hedeflemekte olup verilerin analizinde nitel araştırma tekniklerinden biri olan içerik analizi tekniğinden yararlanılmıştır. İçerik analizi "Metodolojik araç ve teknikler bütünü, kontrollü yorum yapma, nesnel, sistematik ve nicel yollardan betimleme, önceden belirlenmiş ölçütlere göre inceleme, anlam çıkarma, açık talimatlara göre nicelleştirme işlemi, niteli nicele dönüştüren bir işlem, kavramlarn ölçülmesi ve belirli bir anlam çıkarılması için kategorilere ayırma" olarak tanımlanmaktadır (Tavşancll ve Aslan, 2001, s.21-22). İçerik analizi yöntemi ile betimsel analizde özetlenen ve yorumlanan veriler daha derin bir işleme tabi tutulur ve bu analiz sonucunda kavram ve temalar belirlenir. Daha sonra yapılan bu betimlemeler açıklanır ve yorumlanır, neden-sonuç ilişkileri irdelenerek bir takım sonuçlara ulaşılır (Creswell, 2017; Yıldırım ve Şimşek, 2018).

Toplumsal cinsiyet ile ilgili araştırmalarda yöntem olarak içerik analizini kullanmak içeriği incelemenin etkilerini ve onu oluşturanların arkasındaki motivasyonları göz önünde bulundurarak teoriyi ortaya koymak açısından yararlı ve önemli olarak değerlendirilmektedir (Rudy, Popova, and Linz, 2010).

\section{Çalışma Materyali}

Erken çocukluk dönemindeki çocuklara yönelik hazırlanan, karakterleri anne, baba ve çocuklardan oluşan aile çizgi filmlerinin incelenmesi amaçlayan bu araştırma için çizgi filmler, ulusal yayın yapan TRT Çocuk ve 
şifreli kanal olan Cartoon Network ve Minika Çocuk kanallarından seçilmiştir. Minika Çocuk ve Cartoon Network tematik çocuk kanalları birden fazla dijital yayın platformunda yer almaktadır. Bu nedenle yerli yapımlar arasından seçilen çizgi filmler, daha fazla kişiye ulaştıkları düşünülerek, ulusal yayın yapan TRT Çocuk kanalı ile birden fazla platformda yer alan şifreli kanallar arasından seçilmiştir.

Araştırmanın amacı doğrultusunda çizgi film seçim kriterleri, çekirdek aile olarak anne, baba, kardeşten oluşan aile üyelerine geniş bir şekilde yer vermesi ve 2019 yılında yayın akışında yer alması, geniş bir izleyici kitlesine ulaşması ve yerli yapım olması olarak belirlenmiştir. Bu kapsamda TRT Çocuk Kanalı'ndaki Canım Kardeşim ve Biz İkimiz; Minika Çocuk Kanalı'nda Neşeli Dünyam; Cartoon Network Kanalı'nda Kral Şakir çizgi filmlerinin bölümleri internetten izlenerek incelenmiştir. Çizgi filmlerin bölümleri seçkisiz olarak atanmakla birlikte tüm aile üyelerinin incelenen bölümlerde yer almasına dikkat edilmiştir. Seçilen çizgi filmler güncel ve televizyonda yüksek izlenme oranlarına sahiptir. TRT Çocuk $1 \mathrm{Kasım}$ 2017 tarihinde reyting sıralamasından çekilme kararı almıştır (http://www.gazeteduvar.com.tr) ancak bu tarihe kadar Canım Kardeşim ve Biz İkimiz çizgi filmleri reyting listesinde ilk 100'e giren programlar arasında yer almaktadır (https://www.medyafaresi.com). Kral Şakir'in 2019 yılında Cartoon Network'ün en çok seyredilen çizgi filmleri arasında yer aldığı görülmektedir (https://cartoonnetworkturkiye.fandom.com/tr/wiki/Ana_Sayfa). Minika Çocuk'ta yayınlanan Neşeli Dünyam çizgi filmi de en çok izlenen ilk 100 program arasında yer almaktadır (https://fav10.net). Seçilen çizgi filmlerin bölümleri televizyonda tekrar tekrar yayınlanmaktadır. Ayrıca internet sitelerinde bu çizgi filmlere ait videoların izlenme/tıklanma sayılarının da oldukça yüksek olduğu görülmektedir. Buna ek olarak bu çizgi filmlerin karakterlerine ait oyuncak, bilgisayar oyunu gibi ürünler piyasada yer almaktadır. İncelenen çizgi filmlerden Canım Kardeşim, Biz İkimiz ve Kral Şakir sinema filmi ya da tiyatro oyunu olarak da karşımıza çıkmakta; seçilen çizgi filmler birden fazla yolla çocuklara ulaşmaktadır.

Araştırmada yer alan Canım Kardeşim, Biz İkimiz ve Neşeli Dünyam çizgi filmleri erken çocukluk dönemindeki okul öncesi ve ilkokul çocuklarına yöneliktir. Kral Şakir ise bu dönemdeki çocukların yanı sıra yetişkinlerin de izleyebileceği bir çizgi film olarak tanıtılmaktadır. TRT Çocuk 
kanalında yer alan Canım Kardeşim ve Biz İkimiz çizgi filmlerinin bazı bölümleri sayılar, harfler gibi eğitici ve öğretici öğeler de içermektedir. Canım Kardeşim çizgi filminden 30 bölüm, Biz İkimiz çizgi filminden 19 bölüm, Kral Şakir çizgi filminden 21 bölüm, Neşeli Dünyam çizgi filminden 13 bölüm olmak üzere toplam 83 bölüm çizgi film analiz edilmiştir. Her çizgi filmin yayınlanan bölümlerinden üçte bir oranında seçim yapılmış; Neşeli Dünyam çizgi filmi araştırma verilerinin toplanması sırasında toplam 13 bölüm yayınlandığı için bu çizgi filmin bölümlerinin tamamı araştırmaya dâhil edilmiştir.

İncelenen her çizgi filmde bir anne ve bir baba karakteri yer almakta olup toplamda dört anne ve dört baba karakteri bulunmaktadır. Kız çocuk sayısı altı, oğlan çocuk sayısı ise beştir. Canım Kardeşim çizgi filminde yer alan ve bebek olan oğlan çocuk karakteri dışında tüm çocukların yaşları okul öncesi ya da ilkokul dönemine aittir. Bu anlamda çizgi filmlerde yer alan anne, baba karakterlerinin sayıları eşit olup kız ve oğlan çocuk sayılarının da birbirine oldukça yakın olduğu görülmektedir. Araştırma kapsamında incelenen çizgi filmlere ve bölümlere Tablo 1'de yer verilmiştir.

\section{Tablo 1. Araştırma Kapsamında Incelenen Çizgi Filmlerin Bölümleri}

\begin{tabular}{lllll}
\hline & Canım Kardeşim & Biz İkimiz & Kral Şakir & Neşeli Dünyam \\
\hline 1 & Zamanı Durdurmayı Denedin mi? & Uçak Oyunu & Çöp Odası & Hoşgeldiniz \\
2 & Annem Gibi Güzel Olmak İstiyorum & Kız Kulesi & Yemek Savaşı & Paylaşmak \\
3 & Annemize Yardım Edelim & Aile İçi Yardımlaşma & Altın Günü & Büyümek \\
4 & Büyüdügümde Ne Olacağım? & Yaz Bölümü & Babalar Yarışıyor & Arkadaşlık \\
5 & Mine'nin Uçurtması Kayboldu & Misafirperverlik & İçimde Biri Var & Kaşifler \\
6 & Muhteşem İzciler Kampta & Hediye Alma & Civcivler Firarda & Sonbahar Rüyası \\
7 & Ailemizin Robotu & Galata Kulesi & Şakir'in Rüyası & Pembe Gezegen \\
8 & Ressam Olmak İstiyorum & Kahvaltı & 1 Nisan & Küçüldük \\
9 & Yeni Kardeş Geliyor & Gizemli Defter & Şakir'in Kopyaları & Doğum Günü Sürprizi \\
10 & Eyvah Mete Nerede? & Nasıl Yemeli? & Gizemli Komşu & Küçük İzciler \\
11 & Anneler Günü & Çok Bilmiş Arda & Kanepe Krallığı & Evim Evim Güzel Evim \\
12 & Peri Bacalarında Büyük Macera & Ağaç hastalandı mı? & Pembik & Neşe ve Yedi Mutlu \\
13 & Doktor Mine ve Kaptan Beyin & Beş Taş & Lunapark & Kardeşiz Biz \\
14 & Mucit Kardeşim & Çöp Kutusu & Kepçe Adam & \\
15 & Bugün Bayram & Sek Sek & Buzdolabı & \\
16 & Kitap Okumak Güzeldir & Serçe & Dinozor Gribi & \\
17 & Bu Nasıl Çalışıor? & Yıldız Kayması & Kaşıç̧ Elması & \\
18 & Fil, At, Şah Mat & Define & Çatı Katı & \\
19 & Dağdaki Kulübe & Orman & Oyun Fuarı & \\
20 & Mine Düzenli Olmayı Öğreniyor & & Saç & \\
21 & Bu Paralar Kimin? & & Muhtişim İkili & \\
22 & Bahçe Başkanı Mine & & & \\
23 & Babamın Doğum Günü & & & \\
24 & Matematik Ne Kadar Kolaymış & & & \\
25 & Bitmeyen Saklambaç & & &
\end{tabular}


Canım Kuzenim Onur

Onur Uzay Aracı Yapıyor

Aferin Onur

Neşeli Kekler Gülümseyen Kurabiye-

ler

30 Tatil Kamp1

\section{Verilerin Analiz Süreci}

Veri analiz sürecinin ilk aşamasında alan yazında toplumsal cinsiyet ile ilgili kuramlar ve çizgi filmlerde toplumsal cinsiyet üzerine yapılan araştırmalar incelenmiştir. Ardından ilgili alan yazın çerçevesinde bir izleme formu oluşturulmuştur. İzleme formu çizgi filmlerdeki toplumsal cinsiyet ile ilgili özellikleri ortaya koymak amaciyla ana karakterler olan anne, baba ve kız çocuk, oğlan çocuk karakterlerinin bulundukları mekânlar, gündelik yaşam eylemleri ve davranış özellikleri kategorilerine ayrılarak hazırlanmıştır. Anne ve baba karakterleri için çocuklarıyla kurdukları iletişim ayrı bir kategori olarak belirlenmiştir. Araştırma kapsamında incelenen her çizgi film bölümünde her bir kategori altında annenin ve babanın, kız ve oğlan çocuğunun çizgi filmde nasıl yer aldığı analiz birim olarak belirlenen eylemleri ve diyalogları çerçevesinde incelenmiştir. Her bir kategoride, kadın ve erkeğin, kız ve erkek çocuğunun çizgi filmde nasıl temsil edildiğine yönelik bilgiler izleme formuna kayıt edilmiştir. Son aşama olarak sayısallaştırma aşamasında, belirlenen kategoriler altında kodların ne kadar oranda tekrarlandığı yüzde ve frekans hesabıyla belirlenerek sayısallaştırılmıştır.

Verilerin analizi sürecinde çizgi filmlerde yer alan anne, baba, kız çocuk, oğlan çocuk karakterlerinin eylemleri ve diyalogları incelenmiş; araştırmanın problemi ve araştırma soruları çerçevesinde temalara ayrılmıştır. Temalar kapsamında anne ve baba ile kız ve oğlan çocuk karakterleri için kodlama tablosu oluşturulmuştur. Kodlamalar, verilerden çıkarılan kavramlara göre yapılmış, analiz edilmiş ve sayısallaştırılmıştır. Sayısallaştırma aşamasında belirlenen kategorilerin ne kadar oranda tekrarlandığ yüzde ve frekans hesabiyla belirlenmiş. ve SPSS programiyla tablolar haline getirilmiştir. Araştırmanın güvenirliği açısından her çizgi film araştırmacı tarafından en az iki kez izlenmiştir. Bunun yanı sıra her çizgi filmden seçkisiz olarak seçilen beş bölüm kapsamında toplam 20 bölüm için veriler 
başka bir araştırmacı tarafından belirlenen kategoriler çerçevesinde kodlanmıştır. Miles ve Huberman tarafından (2019) önerilen Görüş birliği/(Görüş birliği+Görüş ayrılı̆̆ı) X 100 formülü kullanılarak kodlayıcılar arasındaki uyuşma oranı 0.92 olarak hesaplanmıştır. Miles-Huberman güvenirlik formülü değerinin .70'in üzerinde olması araştırma için güvenilir kabul edilmektedir (Miles ve Huberman, 2019). Elde edilen sonuç araştırma için güvenilir kabul edilmiştir.

\section{Bulgular}

$\mathrm{Bu}$ çalışmada yerli yapım çizgi filmlerde anne ve baba ile kız çocuk ve oğlan çocuk karakterleri aracılığıyla toplumsal cinsiyete dair kalıp yarg1lar belirli kategoriler altında incelenmiştir. Önce ana ve yan karakterlerin cinsiyetlerine dair bilgiler sayısal olarak verilmiştir. Sonrasında çizgi filmlerde yer alan anne ve baba karakterlerinin toplumsal cinsiyet kapsamında kamusal alanda bulunma durumları, günlük yaşam etkinlikleri, davranış özellikleri ve çocukla iletişim kategorileri altında hangi düzeyde, hangi cinsiyetteki karakter tarafından gerçekleştirildiği belirlenmiştir. Daha sonra kız ve oğlan karakterlerinin toplumsal cinsiyet açısından kamusal alanda bulunma durumları, günlük yaşam etkinlikleri, davranış özellikleri, eylemleri ve söylemleri kapsamında hangi düzeyde hangi cinsiyetteki karakter tarafından gerçekleştirildiğine yer verilmiştir.

\section{Çizgi Filmlerde Yer Alan Ana Karakterlerin ve Yan Karakterlerin Cinsi-} yetleri: İncelenen çizgi filmlerdeki karakterler ana karakterler ve yan karakterlere ayrılmış ve cinsiyetlerine göre incelenmiştir. Çizgi filmlerdeki ana ve yan karakterlerin cinsiyetlerine dair bilgiler Tablo 2' de yer almaktadir.

Tablo 2. Çizgi Filmlerde Yer Alan Ana ve Yan Karakterlerin Cinsiyetlerine Göre Da$\breve{g}$ ılımı

\begin{tabular}{llllllll}
\hline \multirow{2}{*}{ Karakter Türü } & \multirow{2}{*}{ Karakter } & \multicolumn{2}{c}{ Kadın } & \multicolumn{2}{c}{ Erkek } & \multicolumn{2}{c}{ Toplam } \\
\cline { 3 - 8 } & & $\mathbf{f}$ & $\mathbf{\%}$ & $\mathbf{f}$ & $\mathbf{\%}$ & $\mathbf{f}$ & $\mathbf{\%}$ \\
\hline Ana Karakter & İnsan & 10 & 52.6 & 9 & 47.4 & 19 & 100 \\
& İnsan & 20 & 22 & 71 & 78 & 91 & 100 \\
\multirow{3}{*}{ Yan Karakter } & Obje & 2 & 13.3 & 13 & 86.7 & 15 & 100 \\
& Hayvan & 3 & 50 & 3 & 50 & 6 & 100 \\
& Yan Karakter Toplam & 25 & 22.3 & 87 & 77.7 & 112 & 100
\end{tabular}


Tablo 2 incelendiğinde ana karakterlerin tamamının insan olduğu görülmektedir. Ana karakterler cinsiyet açısından incelendiğinde kadın ve erkek oranının birbirine yakın olduğu görülmektedir. Kadınlar \%52.6 oranında yer alırken erkekler \%47.4 oranında yer almaktadır. Yan karakterler incelendiğinde ise yan karakterlerin insan, obje ve hayvan karakterleri olarak yer aldıkları görülmektedir. İnsan olan karakterlerin \%22'si kadın, \%78'i erkektir. Buzdolabı, robot, çamaşır makinesi gibi obje formundaki karakterlerin \%13.3'ü kadın, \%86,7'si erkektir. Hayvan karakterlerinin $\% 50$ 'si kadın, \%50'si erkek olup yan karakterlerin tamamı birlikte değerlendirildiğinde \%22.3'ünün kadın, \%77.7'sinin erkek olduğu görülmektedir. Buna göre yan karakterlerin büyük çoğunluğunun erkek olduğu ve televizyon, navigasyon gibi cihazlardan gelen diş seslerin tamamının da erkek sesi olduğu tespit edilmiştir. Bu cihazlar teknolojik cihazlardır ve teknoloji ile erkek sesinin ilişkilendirilmesi söz konusu olmuştur.

\section{Anne ve Baba Karakterlerinin Toplumsal Cinsiyet Kapsaminda Incelen-} mesine Dair Bulgular: Anne ve baba karakterlerine ilişkin toplumsal cinsiyet kalıp yargıları dört kategori altında incelenmiştir. Bunlardan birincisi karakterlerin kamusal alanda yer alma, ikincisi günlük yaşam etkinlikleri, üçüncüsü davranış özellikleri, dördüncüsü ise çocukla iletişim olarak belirlenmiştir.

Tablo 3. Anne ve Baba Karakterlerin Kamusal Alanda Yer Alma Durumlar

\begin{tabular}{llllll}
\hline Karakterler & \multicolumn{5}{l}{ Kamusal Alanda Yer Alma } \\
\hline \multirow{3}{*}{ Anne } & Canım Kardeşim & Biz İkimiz & Neşeli Dünyam & Kral Şakir & Toplam \\
Baba & 4 & 7 & 2 & 5 & 18 \\
\hline
\end{tabular}

Anne ve baba karakterlerinin kamusal alanda yer alma durumlarının tespiti için hangi mekânlarda bulundukları incelenmiştir. Tüm çizgi filmler ile birlikte incelendiğinde, baba karakterlerinin ( $\mathrm{f}=37)$ anne karakterlerden ( $\mathrm{f}=18$ ) daha fazla kamusal alanda yer aldığı görülmektedir. İncelenen çizgi filmlerde mekânlar büyük ölçüde evin içi ve evin bahçesidir ve tüm karakterler genellikle bu mekânlarda yer almaktadır. Ancak karak- 
terler zaman zaman kütüphane, müze, orman, oyun parkı gibi evin dışındaki alanlarda da bulunmaktadır. Bu mekânlar incelendiğinde baba karakterlerinin anne karakterlerine göre daha fazla kamusal alanda yer aldıkları; anne karakterinin yer aldığı kamusal mekânların ise daha sınırlı olduğu görülmektedir.

Tablo 4. Anne ve Baba Karakterlerinin Günlük Yaşam Etkinlikleri

\begin{tabular}{llllllll}
\hline Kategori & Kodlar (Eylemler) & Anne & \multicolumn{3}{c}{ Baba } & \multicolumn{2}{c}{ Toplam } \\
\cline { 3 - 7 } & & $\mathbf{f}$ & $\mathbf{\%}$ & $\mathbf{f}$ & $\mathbf{\%}$ & $\mathbf{f}$ & $\mathbf{\%}$ \\
\hline \multirow{4}{*}{ Günlük yaşam etkin- } & Yemek ile ilgili işleri yapma & 25 & 89.3 & 3 & 10.7 & 28 & 100 \\
likleri & Bebek bakımı & 22 & 91.7 & 2 & 8.3 & 24 & 100 \\
& Gazete/kitap okuma & 9 & 52.9 & 8 & 47.1 & 17 & 100 \\
& Ev işi yapma & 6 & 26.1 & 17 & 73.9 & 23 & 100 \\
& İşe gitme/işten gelme & 5 & 71.4 & 2 & 28.6 & 7 & 100 \\
& Ulaşım aracı kullanma & 4 & 23.5 & 13 & 76.5 & 17 & 100 \\
& Tamir işleri yapma & 2 & 8.3 & 22 & 91.7 & 24 & 100 \\
& Güç gerektiren iş yapma & 1 & 7.1 & 13 & 92.9 & 14 & 100 \\
\hline
\end{tabular}

Tablo 4'te anne ve baba karakterlerinin günlük yaşam eylemlerini hangi oranda gerçekleştirdikleri incelenmiştir. Yemek ile ilgili işleri yapma $(\% 89,3)$, bebek bakımı $(\% 91,7)$, ev işi yapma $(\% 71,4)$ eylemlerinin büyük oranda anne karakterleri tarafından gerçekleştirildiği görülmektedir. Baba karakterleri yemek, ev ve bebek bakımı ile ilgili işleri ancak olağanüstü durumlarda ve çok düşük bir oranda gerçekleştirmektedir. Baba karakterleri ulaşım aracı kullanma (\%91,7), çocukla vakit geçirme $(\% 73,9)$, işe gitme/işten gelme $(\% 76,5)$, tamir işleri yapma $(\% 92,9)$, güç gerektiren işleri yapma (\%100) ile ilgili günlük yaşam etkinliklerinde anne karakterlerden daha fazla oranda yer almaktadır. Yalnızca gazete/kitap okuma eyleminin anne ve baba karakterleri açısından birbirine yakın oranda gerçekleştirildiği görülmektedir. Bunun dişında yer alan eylemlerde anne ve baba karakterleri birlikte sorumluluk almamakta ve işleri paylaşmamaktadır. Gündelik yaşam eylemlerinin toplumsal cinsiyet eşitliği göz ardı edilerek gerçekleştirilmekte olduğu; evdeki iş bölümü birbirinden ayrılmış ve cinsiyet kalıp yargılarına uygun bir şekilde gösterildiği görülmektedir. 
Tablo 5. Anne ve Baba Karakterlerinin Davranış Özellikleri

\begin{tabular}{|c|c|c|c|c|c|c|c|}
\hline \multirow[t]{2}{*}{ Kategori } & \multirow[t]{2}{*}{ Kodlar (Özellikler) } & \multicolumn{2}{|c|}{ Anne } & \multicolumn{2}{|c|}{ Baba } & \multicolumn{2}{|c|}{ Toplam } \\
\hline & & f & $\%$ & f & $\%$ & f & $\%$ \\
\hline \multirow{11}{*}{$\begin{array}{l}\text { Anne ve baba karakter- } \\
\text { lerin davranış özellik- } \\
\text { leri }\end{array}$} & Domestik olma & 35 & 94.6 & 2 & 5.4 & 37 & 100 \\
\hline & Duygusal olma & 27 & 71 & 11 & 29 & 38 & 100 \\
\hline & Yönlendiren kişi olma & 18 & 31.6 & 39 & 68.4 & 57 & 100 \\
\hline & Dış görünüșe ve güzelliğe önem verme & 16 & 76.2 & 5 & 23.8 & 21 & 100 \\
\hline & Düzenli ve temiz olma & 12 & 85.7 & 2 & 14.3 & 14 & 100 \\
\hline & Bilgili olma & 12 & 29.3 & 29 & 70.7 & 41 & 100 \\
\hline & Bilim ve teknoloji ile ilgili olma & 9 & 18.4 & 40 & 81.6 & 49 & 100 \\
\hline & Problem çözme & 5 & 19.2 & 21 & 80.8 & 26 & 100 \\
\hline & Kendine güvenme & 0 & 0 & 33 & 100 & 33 & 100 \\
\hline & Eğlenceli olma & 0 & 0 & 12 & 100 & 12 & 100 \\
\hline & Çocuk ruhlu olma & 0 & 0 & 9 & 100 & 9 & 100 \\
\hline
\end{tabular}

Tablo 5'te incelenen çizgi filmlerde anne ve baba karakterlerinin davranış özelliklerine yer verilmiştir. Anne karakterlerinin domestik olma (\% 94,6), duygusal olma (\%71), dış görünüşe ve güzelliğe önem verme $(\% 76,2)$, düzenli ve temiz olma $(\% 85,7)$ özelliklerini baba karakterlere göre daha fazla gösterdikleri görülmektedir. Baba karakterlerinin ise bilim ve teknoloji ile ilgili olma $(\% 81,6)$, kendine güvenme (\%100), yönlendiren kişi olma (\%68,4), bilgili olma $(\% 70,7)$, problem çözme $(\% 80,8)$, eğlenceli olma (\%100), çocuk ruhlu olma (\%100) özelliklerinde daha yüksek oranda temsil edildikleri görülmektedir. Annelerin ve babaların bu davranış özelliklerinin kadınlara ve erkeklere atfedilen toplumsal cinsiyet kalıp yargılarını yansıttığı görülmektedir.

Tablo 6. Anne ve Baba Karakterlerinin Çocukla İletişim Kurma Özellikleri

\begin{tabular}{|c|c|c|c|c|c|c|c|}
\hline \multirow[t]{2}{*}{ Kategori } & \multirow[t]{2}{*}{ Kodlar (Özellikler) } & \multicolumn{2}{|c|}{ Anne } & \multicolumn{2}{|c|}{ Baba } & \multicolumn{2}{|c|}{ Toplam } \\
\hline & & $\overline{\mathrm{f}}$ & $\%$ & $\mathrm{f}$ & $\%$ & $\mathrm{f}$ & $\%$ \\
\hline \multirow{4}{*}{$\begin{array}{l}\text { Anne ve baba karakterlerinin çocuk- } \\
\text { larla iletişim kurma özellikleri }\end{array}$} & Öğüt verici olma & 30 & 66.7 & 15 & 33.3 & 45 & 100 \\
\hline & Uyarıda bulunma & 11 & 91.7 & 1 & 8.3 & 12 & 100 \\
\hline & Geleneksel değerleri aktarma & 7 & 77.8 & 2 & 22.2 & 9 & 100 \\
\hline & Arkadaş gibi olma & 3 & 17.7 & 14 & 82.3 & 17 & 100 \\
\hline
\end{tabular}

Çizgi filmleri toplumsal cinsiyet açısından değerlendirmek amaciyla incelenen diğer bir kategori anne ve baba karakterlerin çocuklarıyla kurdukları iletişim olarak belirlenmiştir. Çocukla iletişim özellikleri açısından hangi ebeveynin hangi özelliğe hangi oranda sahip olduğu incelenmiş, bu özelliklere Tablo 6'da yer verilmiştir. Buna göre anne karakterleri çocukla iletişimde uyarıda bulunma $(\% 91,7)$, geleneksel değerleri aktarma $(\% 77,8)$, öğüt verici olma $(\% 66,7)$ özellikleri ile temsil edilirken, baba karakterleri arkadaş gibi olma (\%82,3) özelliği ile daha fazla oranda temsil edilmektedir. Anne ve baba karakterleri çocuklarıyla iletişimleri açısından 
birbirlerine zıt olarak nitelendirilebilecek özellikler sergilemekte ve çocuklarıyla iletişimlerinde de toplumsal cinsiyet eşitsizliğine dair iletiler bulunmaktadir.

Kız ve Oğlan Çocuk Karakterlerinin Toplumsal Cinsiyet Kapsamında İncelenmesine Dair Bulgular: Çizgi filmlerin kız ve oğlan çocuk karakterleri aracılığıyla toplumsal cinsiyet açısından incelenmesi için birinci kategori kız ve oğlan çocuklarının kamusal alanda bulunma durumları, ikinci kategori kız ve oğlan çocuklarının gündelik yaşam etkinlikleri ve üçüncü kategori kız ve oğlan çocuklarının davranış özellikleri olarak belirlenmiştir.

Tablo 7. Kız ve Oğlan Çocuklarının Kamusal Alanda Bulunma Durumları

\begin{tabular}{llllll}
\hline Cinsiyet & \multicolumn{1}{l}{ Kamusal Alanda Bulunma } & & & \\
\hline & Canım Kardeşim & Biz İkimiz & Neşeli Dünyam & Kral Şakir & Toplam \\
Kız Çocuk & 10 & 6 & 4 & 9 & 29 \\
Oğlan Çocuk & 10 & 6 & 4 & 18 & 38 \\
\hline
\end{tabular}

Kız ve oğlan çocuklarının kamusal alanda bulunma durumları Tablo 7'de gösterilmiştir. Tüm çizgi filmler birlikte değerlendirildiğinde oğlan çocuklarının kız çocuklarına oranla kamusal alanda daha fazla temsil edildiği görülmektedir. İzlenen çizgi filmlerde karakterler büyük ölçüde evin içinde ya da evin bahçesinde bulunmaktadırlar. Ana karakter olan kız ve oğlan çocuklarının kamusal alanda bulunma durumları incelendiğinde Canım Kardeşim, Biz İkimiz ve Neşeli Dünyam çizgi filmlerinde kız ve oğlan çocuklarının eşit sayıda kamusal alanda bulundukları; Kral Şakir çizgi filminde ise oğlan çocuğunun kız çocuğundan daha fazla kamusal alanda yer aldığı görülmektedir. Hem kız çocukları hem de oğlan çocukları kamusal alan kapsamında genelde oyun parkı, orman, deniz kenarı, okul gibi mekânlarda bulunmaktadırlar.

Tablo 8. Kız ve Oğlan Çocuklarının Günlük Yaşam Etkinlikleri

\begin{tabular}{|c|c|c|c|c|c|c|c|}
\hline \multirow[t]{2}{*}{ Kategori } & \multirow[t]{2}{*}{ Kodlar (Eylemler) } & \multicolumn{6}{|c|}{ K1z ÇocuğuOğlan ÇocuğuToplam } \\
\hline & & f & $\%$ & f & $\%$ & $\mathrm{f}$ & $\%$ \\
\hline \multirow{6}{*}{$\begin{array}{l}\text { Gündelik yaşam et- } \\
\text { kinlikleri }\end{array}$} & Oyun Oynama & 32 & 56.1 & 25 & 43.9 & 57 & 100 \\
\hline & Ev işi yapma (Yemek/temizlik/bebek bakımı) & 16 & 84.2 & 3 & 15.8 & 19 & 100 \\
\hline & Tamir işi yapma & 3 & 23.1 & 10 & 76.9 & 13 & 100 \\
\hline & $\begin{array}{l}\text { Pasif etkinlikler yapma (Kitap okuma/Resim yapma/Ödev } \\
\text { yapma) }\end{array}$ & 27 & 75 & 9 & 25 & 36 & 100 \\
\hline & Güç gerektiren iş yapma & 1 & 12.5 & 7 & 87.5 & 8 & 100 \\
\hline & Ulaşım aracı kullanma & 4 & 36.4 & 7 & 63.6 & 11 & 100 \\
\hline
\end{tabular}

İncelenen çizgi filmlerde kız ve oğlan çocuk karakterlerinin ev içinde ve ev dişında gerçekleştirdikleri eylemler, gündelik yaşam etkinlikleri 
kapsamında Tablo 8'de gösterilmiştir. Oyun oynama eyleminin hem kız hem de oğlan çocuklar tarafından en fazla ve birbirine yakın oranda gerçekleştirilen eylem olduğu görülmektedir. Diğer günlük yaşam etkinlikleri incelendiğinde $\mathrm{k}$ ız çocukları ev işi yapma $(\% 84,2)$, pasif etkinlikler yapma (\%75) etkinliklerinde oğlan çocuklara göre daha fazla yer almaktadır. Oğlan çocuklarının ise güç gerektiren iş yapma (\%87,5), tamir işi yapma $(\% 76,9)$, ulaşım aracı kullanma $(\% 63,6)$ eylemlerinde kız çocuklara oranla daha fazla yer aldıkları görülmektedir. Çocuk karakterlerin eylemlerinin toplumsal cinsiyet kalıp yargıları çerçevesinde temsil edilmekte olduğu ve cinsiyete göre farklılaştı̆̆ görülmektedir.

Tablo 9. Kız ve Oğlan Çocuğu Karakterlerinin Davranış Özellikleri

\begin{tabular}{|c|c|c|c|c|c|c|c|}
\hline \multirow[t]{2}{*}{ Kategori } & \multirow[t]{2}{*}{ Kodlar (Özellikler) } & \multicolumn{2}{|c|}{$\begin{array}{l}\text { Kız } \\
\text { Çocuğu }\end{array}$} & \multicolumn{4}{|c|}{ Oğlan Çocuğu Toplam } \\
\hline & & $\mathbf{f}$ & $\%$ & $\mathrm{f}$ & $\%$ & $\mathbf{f}$ & $\%$ \\
\hline \multirow{13}{*}{$\begin{array}{l}\text { Kız ve oğlan çocuğu karak- } \\
\text { terlerinin davranış özellik- } \\
\text { leri }\end{array}$} & Hayalperest olma & 68 & 95.8 & 3 & 4.2 & 71 & 100 \\
\hline & Duygusal olma & 26 & 59.1 & 18 & 40.9 & 44 & 100 \\
\hline & Diş görünüsse ve güzelliğe önem verme & 23 & 100 & 0 & 0 & 23 & 100 \\
\hline & Yönlendiren kişi olma & 22 & 51.2 & 21 & 48.8 & 43 & 100 \\
\hline & Problem çözme & 14 & 31.8 & 30 & 68.2 & 44 & 100 \\
\hline & Övgü alma & 14 & 35 & 26 & 65 & 40 & 100 \\
\hline & Bilgili olma & 13 & 54.2 & 11 & 45.8 & 24 & 100 \\
\hline & Düzenli ve temiz olma & 12 & 85.7 & 2 & 14.3 & 14 & 100 \\
\hline & Bir görüşü destekleme & 12 & 92.3 & 1 & 7.7 & 13 & 100 \\
\hline & Akıl yürütme & 12 & 38.7 & 19 & 61.3 & 31 & 100 \\
\hline & Bilim ve teknoloji ile ilgili olma & 6 & 14.6 & 35 & 85.4 & 41 & 100 \\
\hline & Kendine güvenme & 5 & 11.4 & 39 & 88.6 & 44 & 100 \\
\hline & Rekabetçi olma & 4 & 25 & 12 & 75 & 16 & 100 \\
\hline
\end{tabular}

İncelenen çizgi filmlerde kız ve oğlan çocuk karakterlerinin eylemleri ve diyalogları analiz edilerek davranış özellikleri Tablo 9'da gösterilmiştir. Kız çocukları dış görünüşe ve güzelliğe önem verme (\%100), hayalperest olma $(\% 95,8)$, bir görüşü destekleme $(\% 92,3)$, düzenli ve temiz olma $(85,7)$, duygusal olma $(59,1)$, bilgili olma $(\% 54,2)$ özelliklerinde oğlan çocuklara göre daha fazla oranda yer almaktadır. Yönlendiren kişi olma özelliğinin kız ve oğlan çocukları için birbirine yakın oranda olduğu görülmektedir. Oğlan çocuklarının ise kendine güvenme (\%88,6), bilim ve teknoloji ile ilgili olma $(\% 85,4)$, rekabetçi olma $(\% 75)$, problem çözme $(\% 68,2)$, övgü alma (\%65), akıl yürütme $(\% 61,3)$ davranış özelliklerinde kız çocuklara oranla daha fazla temsil edilmektedir. Kız çocuklarının ve oğlan çocuklarının davranış özelliklerine toplumsal cinsiyet kalıp yarg1ları çerçevesinde yer verildiği görülmektedir. 


\section{Tartışma ve Sonuç}

İncelenen çizgi filmlerde karakterlerin cinsiyete göre dağılımında ana karakterlerde kadın ve erkek oranının birbirine yakın olduğu; yan karakterlerde ise erkek karakterlerin kadın karakterlerden daha fazla olduğu sonucuna ulaşılmıştır. Televizyon, navigasyon gibi araçlardan gelen tüm dış seslerin de erkeklere ait olduğu görülmüştür. Bu durum farklı çalışmalardan elde edilen sonuçlarla desteklenmektedir. Televizyonda reklamların seslendirilmesinde de \%80 oranında otoriteyi temsil ettiği düşünülen erkek sesi kullanılmaktadır (Browne, 2014). Ayrıca medyada çocuklara yönelik olan yayınlarda erkek karakterlerinin sayıca daha baskın olması farklı araştırmalarda karşımıza çıkmaktadır (Edwin ve diğ., 2012; Götz ve diğ., 2008; Hentges ve Case, 2012; Koeman, Peeters ve D’Haenens, 2007; Rozario, Masilamani ve Arulchelvan, 2018; Walsh ve Leaper, 2020). Erkek karakterlerin kadın karakterlerden sayıca daha fazla olması, kadınların yetersiz temsili bağlamında tartışılmaktadır (Ruble, Martin ve Berenbaum, 2006). Çocuklar çizgi film karakterlerinden kendilerine rol model olarak kendileri ile aynı cinsiyette olan karakterleri seçmektedir (Kidenda, 2018; Knobloch, Callison, Chen, Fritzsche ve Zillmann, 2005; Oruç, Tecim ve Özyürek, 2011). Bu nedenle bu durum kız çocukları açısından dezavantajlı olarak görülebilir. Bu durumda incelenen çizgi filmlerde kadınların yeterli sayıda temsil edilmemesi toplumsal cinsiyet açısından eşitsizliğe dair bir mesaj iletmesi olarak yorumlanmaktadır.

Anne ve baba karakterlerinin kamusal alanda bulunma durumları incelendiğinde baba karakterlerinin anne karakterlerine göre daha fazla ve çeşitlilikte kamusal alana ait mekânlarda bulundukları ortaya çıkmıştır. Babalar kamusal alanda, dış dünya ile etkileşim halinde olmalarına karş1lık olarak anneler özel yer almaktadır. Kız ve oğlan çocukların yer aldıkları mekânlar incelendiğinde Kral Şakir çizgi filmi dışında bütün çizgi filmlerde kız ve oğlan çocukların kamusal alanda eşit sayıda bulundukları sonucuna ulaşılmıştır. Kral Şakir çizgi filminde oğlan çocuk kız çocuktan daha fazla kamusal alanda yer almaktadır. Kız çocuklarının annelerin kamusal mekânda bulunma durumlarında olduğu kadar dezavantajlı olmadığı görülmektedir.

$\mathrm{Bu}$ çalışmanın bulgularına benzer olarak TRT Çocuk'ta yayınlanan çizgi filmlerinin incelendiği çalışmalarda kadın karakterlerin çoğunlukla 
özel alan olarak nitelendirilen ev içinde; erkek karakterlerin ise evin dışındaki kamusal alana ait mekânlarda gösterildiği bulunmuştur (Saraç, 2018; Şen, 2020; Kalaycı, 2015; Yağan ve diğg., 2017). Kadınların ve erkeklerin belirli rol ya da durumlardaki betimlemelerinin sıklığının ölçüldüğü içerik analizlerinin yapıldığı çalışmalarda çoğu zaman kız çocuklarının ve kadınların özellikle kamusal alandaki görünmezliklerine ilişkin sonuçlara ulaşılmaktadır (Bilton ve diğ., 2009, s.149). Çizgi filmlerin toplumsal cinsiyet açısından incelendiği çalışmalarda kadınların özel alanda yer alarak ev içindeki sorumluluklarla ilişkilendirildiği görülmektedir (Fischer, 2010). Benzer şekilde toplumsal cinsiyet eşitliğinin incelendiği ders kitapları (Gümüşoğlu, 2008; Sarıtaş ve Şahin, 2018) ve çocuk kitapları (Bağçeli Kahraman ve Özdemir, 2019; Oğuz Rollas, 2017) ile ilgili araştırmalar da özellikle görsellerde kadınların daha çok özel alanda, erkeklerin ise kamusal alanda gösterildiğine işaret etmektedir. Çizgi filmler de dâhil olmak üzere çocuklara ulaşan pek çok kaynağın, kamusal alan-özel alan bağlamında toplumsal cinsiyet eşitsizliğine dair iletilere sahip olduğu görülmektedir. Günümüzde kadınlar sıklıkla kamusal alanda yer alırken incelenen çizgi filmlerde bu durum yeterince temsil edilmemektedir. Bu sonuç, özel alanın kadınlara, kamusal alanın ise erkeklere ait olduğuna dair toplumsal cinsiyet eşitsizliğinin incelenen çizgi filmler aracılığıyla yeniden üretilmiş olduğu şeklinde yorumlanmaktadır.

Araştırmanın sonuçlarına göre incelenen çizgi filmlerde anne, baba karakterlerinin ve kız çocuk, oğlan çocuk karakterlerinin gündelik yaşam etkinliklerinde birbirinden farklı oranlarda temsil edildikleri görülmektedir. Buna ek olarak kız çocuklarının eylemlerinin anneler ile oğlan çocuklarının eylemlerinin ise babalar ile oldukça benzer olduğu görülmüştür. Anne ve kız çocukları karakterleri yemek yapma, ev ve bakım ile ilgili işleri yapma etkinliklerinde daha çok temsil edilmişlerdir. Baba ve oğlan çocuk karakterleri ise ulaşım aracı kullanma, tamir işleri, güç gerektiren işleri gerçekleştirirken daha yüksek oranda görülmektedir. Ayrıca baba karakterleri işe giderken ya da işten gelirken anne karakterlere göre daha çok gösterilmiştir. Evdeki iş bölümünün cinsiyetlere göre birbirinden ayrı ve cinsiyet kalıp yargılarına uygun bir şekilde temsil edildiği görülmektedir.

Bireyler gündelik eylemler aracılığıyla bir dizi kalıcı model inşa etmekte olup cinsiyet de gündelik eylemler ile oluşturulan bir olgu olarak 
açıklanabilir. İnsanlar gündelik eylemleri üzerinden cinsiyetlerinden beklenen özelliklere uygun özellikler sergilemekte ve cinsiyetlerini bu şekilde inşa ve icra etmektedir. Bu süreçte toplumsal cinsiyete dair eşitsizlikler yeniden üretilmektedir (Berktay, 2011, s.16). Bu çalışmanın sonuçları da dâhil olmak üzere farklı çalışmalarda çizgi filmdeki karakter temsilleri aracılığıyla bu eşitsizliğin yeniden üretildiğine dair sonuçlara ulaşılmıştır. Örneğin Özsoy ve Taşdelen (2016) yaptıkları araştırmada TRT Çocuk'ta yayınlanan Pepee çizgi filminde annenin araba kullanma eylemini gerçekleştirirken görünmesine rağmen baba varken annenin arabayı kullanmıyor oluşu cinsiyet kalıp yargıları ile ilişkilendirilmiş ve ailedeki iktidar kaynağı olarak babayı işaret ettiğine dair bir mesaj olduğu belirtilmiştir. Çizgi filmleri toplumsal cinsiyet açısından inceleyen çalışmalarda bakım verme kapsamında çocukla ilgilenme eyleminin büyük ölçüde anneler tarafından gerçekleştirildiği görülmektedir (Duman ve Koçtürk, 2021; Kalayc1, 2015; Muratoğlu Pehlivan, 2019; Yağan ve diğ., 2017). Saraç (2018) tarafından yapılan ve Niloya çizgi filminin incelendiği çalışmada kadınların ev içinde çocuk bakımı ve ev işleri ile meşgul oldukları, erkeklerin ise akıl ve fiziksel güç gerektiren işlerle uğraştıkları tespit edilmiştir. Yurtdışında yapılan çalışmalarda da benzer sonuçlara ulaşılmıştır. Araştırma sonuçları çizgi filmlerde kadınların daha çok ev işlerinde temsil edildiğini, erkeklerin ise tamir işleri ve güç gerektiren işleri gerçekleştirmede ön plana çıktığını göstermektedir (Jaggi, 2015; Walsh ve Leaper, 2020; Zaheen, Manzoor ve Safdar, 2020). Bu çalışmanın sonuçları da evdeki iş bölümünün, cinsiyetlere göre birbirinden ayrı ve cinsiyet kalıp yargılarına uygun bir şekilde temsil edildiği şeklinde değerlendirilmektedir.

$\mathrm{Bu}$ çalışmada diğer çalışmalardan farklı olarak babaların günlük eylemlerinde çocuk ile vakit geçirme durumları annelerden daha fazla gerçekleştiği görülmüştür. Bu durum günümüzde değişen babalık rolleri ile ilişkilendirilebilir. Günümüzde babalığın bir değişim içinde olduğu ve çocuklarla az iletişim kuran, otoriter baba algısının değiştiği görülmektedir (Barutçu ve Hıdır, 2016; Kuzucu 2011; Wall ve Arnold, 2007). Ayrıca çocukla vakit geçirme eylemi babanın bilgi aktarımını sağlayan ve bilgili olma özelliğini pekiştirecek bir zaman dilimi olarak da yorumlanabilir.

Farklı cinsiyete sahip karakterlerin gündelik yaşam eylemlerinin birbirinden farklılaşması gibi anne ve baba karakterleri ile kız ve oğlan çocuk karakterlerinin birbirinden farklı davranış özellikleri ile temsil edildikleri 
görülmektedir. Anne karakterleri düzenli ve temiz olma, diş görünüşe ve güzelliğe önem verme, duygusal olma, domestik olma özelliklerine sahip olarak gösterilmektedir. Baba karakterleri kendine güvenme, yönlendiren kişi olma, problem çözme özelliklerine sahip, bilgili, bilim ve teknoloji ile ilgili, eğlenceli ve çocuk ruhlu olma özellikleri ile ön plana çıkmaktadır. Anne ve baba karakterlerinin bu davranış özelliklerinin kadınlara ve erkeklere atfedilen toplumsal cinsiyet kalıp yargılarını yansıttığı görülmektedir. Benzer şekilde kız çocuk karakterlerinin anne karakterleri gibi düzenli ve temiz olma, diş görünüşe ve güzelliğe önem verme, duygusal olma, hayalperest olma özellikleri ile temsil edildikleri görülmüştür. Bunların yanı sıra girdikleri diyaloglarda özellikle oğlan çocuklarının görüşlerini destekleyen karakterler olarak temsil edilmişlerdir. Oğlan çocuk karakterlerinin ise baba karakterlere benzer şekilde kendine güvenme, akıl yürütme, bilgili olma, bilim ve teknoloji ile ilgili olma, rekabetçi olma özellikleri ile ön plana çıtıkları görülmektedir. Övgü alarak eylemleri ve söylemleri ödüllendirilen karakterler de daha çok oğlan çocukları olmuştur. Oğlan çocukları akıllı, problem çözen, bilim ve teknoloji ile ilgilenen, akıl yürüten, rekabetçi karakterler olarak diş dünya ile daha ilişkili olarak temsil edilmişlerdir. Kız çocuklarının temsil edildiği dış görünüşe ve güzelliğe önem verme, duygusal ve hayalperest olma dış dünya ile bağlantı kurmada öne çıan özellikler değildir. Öte yandan kız çocuklarının kendi fikirlerini belirtmelerinden çok oğlan karakterlerini onaylayan kişiler olarak temsil edilmelerinin de ikinci planda kalmalarına hizmet etmekte olduğu söylenebilir. İncelenen çizgi filmlerde oğlan çocukları daha fazla ön planda temsil edilmiş; daha çok övgü almış ve oğlan çocukların yaptıkları daha çok desteklenmiş ve övülecek kadar değerli görülmüştür. Cinsiyet kalıp yargıları çerçevesinde kadınlardan sıcak, şefkatli, özverili, sevgi dolu ve yumuşak; erkeklerden ise güçlü, üretken, kendine güvenen, iddialı özellikler taşımaları beklenmektedir (Güler, 2014). Bu araştırmanın sonuçlarına göre incelenen çizgi filmlerde karakterlerin davranış özelliklerinin toplumsal cinsiyet kalıp yargılarını içerdiği görülmektedir. Bu durum farklı araştırmalarda da karşımıza çıkmaktadır. Keloğlu İşler (2014) tarafından yapılan çalışmada da TRT Çocuk kanalındaki çizgi filmlerde baba karakterlerinin her şeye gücü yeten, her türlü probleme çözüm bulan güçlü baba rolleri ile temsil edildiklerini; anne karakterlerin özelliklerinin 
ise domestik özelliklere sahip olma çerçevesinde verildiği ortaya koyulmuştur. Özen Uyar ve Yilmaz Genç (2017) ve Ünlü (2017), bu araştırmanın sonuçları ile benzer şekilde TRT Çocuk kanalındaki çizgi filmlerde hem kadınlara hem de erkeklere yönelik toplumsal cinsiyet rollerinin üretilmesine neden olacak iletiler sunulduğu sonucuna ulaşmışlardır. Yurt dişında yapılmış çalı̧̧malarda da çocuklara yönelik çizgi filmlerde kadın karakterlerinin güzellik ile ilişkilendirildikleri ve domestik özellikler taşıdıkları bulunmuştur (Dundes, 2001; England, Descartes ve Collier Meek, 2011; González, Paniagua, Thornborrow ve Jordán, 2020; Götz ve diğ., 2008; Towbin, Haddock, Zimmerman, Lund ve Tanner, 2004; Wiersma, 2000). Yapılan araştırmalarda, erkek karakterlerin ortak olarak güçlü, bağımsız, bilim ve teknoloji ile ilgili, cesur, girişken, rekabetçi ve akıllı olma gibi özellikler ile temsil edilmekte olduğu sonucuna ulaşılmıştır (Aley ve Hahn, 2020; Fischer, 2010; Thompson ve Zerbinos 1995; Walsh ve Leaper, 2020; Sheikh, 2017). Aubrey ve Harrison (2004) çocukların favori televizyon programlarını inceledikleri çalışmalarında, erkek karakterlerin kadın karakterlere göre daha çok soru cevapladıkları, başkalarına emir verdikleri, beceri gösterdikleri ve bir hedefe ulaştıkları sonuçlarına ulaşmıştır.

Çocuk ruhlu olma özelliği toplumsal cinsiyet kalıp yargıları içinde erkeklere atfedilen bir özellik olarak yer almamaktadır. Bu durumun incelenen çizgi filmlerde babaların eğlenceli olma özelliği taşımaları ile birlikte değerlendirildiğinde, baba karakterlerinin çocuklarla daha iyi anlaşmalarını sağlayan bir özellik olduğu yorumu yapılabilir. Aslında babaların çocuksu özelliklere sahip olmaları ve bunu rahatça göstermeleri ve annelerin de bu özelliği hiç taşımamaları anneleri daha da bir 'anne' yapmaktadır. Çünkü anneler baba karakterlerini de uyarma zorunluluğu hissetmekte ve zaman zaman babalara da çocuklara davrandıkları gibi davranmaktadırlar. Bu durumda da annelik ile ilgili atfedilen görev ve sorumlulukların yeniden üretildiği görülmektedir. Bu özellik babaların davranış özelliklerinde annelere göre daha özgür olduklarına dair bir mesaj olarak da yorumlanabilir. Burada çocuklara iletilen bir diğer mesaj da erkeklerin davranışlarında daha özgür olabileceği ve kadınların da bu durumu hoşgörü ile karşılamaları gerektiği şeklinde değerlendirilebilir.

Anne ve baba karakterlerinin çocuklarıyla iletişimlerinde hangi özellikleri hangi düzeyde üstlendiği ve bu durumun toplumsal cinsiyet kalıp 
yargılarını içerip içermediğinin belirlenmesi için anne ve baba karakterlerinin çocuklarla kurdukları iletişim ayrı bir kategori olarak ele alınmış; babaların günümüzdeki modern babalık rollerini pekiştirecek şekilde çocuklarıla iletişimlerinde arkadaş gibi oldukları belirlenmiştir. Anneler ise çocuklarla iletişimlerinde ögüt verme, uyarıda bulunma ve geleneksel değerleri aktarma özelliklerini daha çok taşımaktadır. Anne ve baba karakterlerinin çocuklarıyla iletişimlerinde de toplumsal cinsiyet eşitsizliğine dair iletiler bulunmaktadır. Anneler, çocuklarını iyi bir şekilde eğitmeyi istemekte ama geleneksel özellikleri taşıma ve geleneksel olanın aktarıcısı olma rolü ile temsil edildikleri için de bunu daha geleneksel yöntemlerle yaparken görülmektedir. Anne ve baba karakterleri çocuklarıla iletişimleri açısından birbirlerine zıt olarak nitelendirilebilecek özellikler sergilemektedir. Baba karakterlerinin eğlenceli ve arkadaş gibi olma özelliklerine karşın anne karakterleri ögüt veren, uyarıda bulunan ve geleneksel değerleri aktaran söylemleri ile babalara göre çocuklarıyla daha ciddi bir iletişim içinde gösterilmektedir.

Annelerin çocuklarla iletişimlerinde daha ciddiyet içinde temsil edilmelerinin iki özelliğe hizmet ettiği şeklinde yorumlanmıştır. Birincisi annelerin çocuklarıyla iletişimlerinde daha ciddi, öğretici ve geleneksel olmaları, babaların günümüzdeki çocuklarıyla daha çok iletişim kuran ve onlarla ilgilenen babalık rollerini kuvvetlendirmektedir. İkinci olarak anne ve baba karakterlerinin çocukla kurdukları iletişimlerinin de günlük eylemlerde ve rol ve davranış özelliklerinde olduğu gibi birbirinden farklı şekilde gösterilmesidir. Çocukla iletişimde babalar arkadaş gibi olma özelliğini üstlenirken annelerin iletişimi ciddiyet ve öğretici olma ekseninde gerçekleşmektedir. Bu ciddiyet annenin özel alanın hâkimi olduğunu vurgulamaktadır. Bu hâkimiyeti çocuklara öğüt vererek, onları uyararak ve geleneksel değerleri aktararak korudukları görülmektedir. Babalar ise çocuklarıyla arkadaş gibi olmakla birlikte evin reisi olma özelliklerini işe giderek, problemleri çözerek, kendine güvenerek, bilgi sahibi olarak, diyaloglarda daha fazla yönlendirme yaparak korumaktadır.

İnal (2020, s.34), medya ürünlerinde yetişkinlerin çocuklarıyla arkadaş gibi olması şeklinde bir imgenin varlı̆̆ından söz etmektedir. Bu durum klasik ve geleneksel rol modellere dayalı anlayışın benimsenmediğini göstermektedir. Çocuk imgesi ise akıllı ve çabuk olgunlaşan şeklinde oluştu- 
rulmakta; ailedeki demokratik bir ortamın gereği hızla bilinçlenmesi üzerinden gösterilmektedir Günümüzde en kabul gören babalık modeli çocuklarıyla ilgilenmeyi, onlarla vakit geçirmeyi içermekte olduğu söylenebilir. Sancar'a (2020) göre, farklı erkeklik ve babalık modelleri kır-kent ayrımı ve sınıfsal farkları oluşturan eğitim ve aile biçimlerine dayalı kültürel sermaye ile ilişkilidir. Egemen babalık modeli, geçimi sağlayan aile babası olarak karşımıza çıkmaktadır. Öte yandan Türkiye' de geleneksel değerler temelinde yer alan babalık ile modern babalık uygulamalarının bir arada olduğu da görülmektedir. En yaygın babalık biçiminin ise erkeğin geçim sorumluluğunu büyük ölçüde tek başına üstlendiği, kadınların sadece ev işi yaptıkları "modernleşmiş" aile babalığı şeklinde ifade etmektedir. İncelenen çizgi filmlerdeki babaların bu babalığa uygun modeller olmaları söz konusudur.

Seçilen çizgi filmlerdeki çocuk karakterlerin ve aile üyelerinin kentli ve orta sınıf Türk kültüründeki değerleri aktardıkları söylenebilir. Çizgi filmlerde anne, baba ve çocuklar ekseninde aile üyelerinin gündelik yaşantılarında başlarından geçen olaylar işlenmektedir. İncelenen çizgi filmlerde, idealize edilmiş bir kurgu içinde heteroseksüel ilişkiler yer almakta ve karakterler cinsiyet ikiliği içinde kalıp yargılarla birlikte sunulmaktadır. Bu araştırmada, kız çocuk ve anne karakterleri üzerinden oluşturulan kadın tipinin en önemli özellikleri özel alanda yer alan, ev ve yemek işleri ile ilgilenen domestik ve duygusal karakterler olmalarıdır. Oğlan çocuk ve baba karakterleri aracılığıyla oluşturulan erkek tipinin ise kamusal alanda yer alan, tamir işlerini yapan, ulaşım aracı kullanan, kendine güvenen, bilgili, bilim ve teknoloji ile ilgili, eylemleri yönlendiren, eğlenceli olma özelliklerini taşıdığı görülmektedir. Çizgi filmlerde kız çocuk karakterlerinin anne ve oğlan çocuklarının baba ile benzer eylemlerde bulunmaları ve benzer davranış özellikleri ile temsil edilmeleri çocukların yetişkin yaşamına bu rolleri taşıyarak, toplumsal cinsiyet rollerini sürdürmede görev almalarını sağlama olarak düşünülmektedir. Anneler ile kız çocukların, babalar ile oğlan çocuklarının eylemleri ile kişilik ve davranış özellikleri neredeyse aynıdır. Kız çocuklarının 'küçük kadınlar' oğlan çocuklarının da 'küçük erkekler' şeklinde temsil edildikleri yorumu yapılabilir. Baba karakterleri değişen babalık rollerine uygun olarak çocuklarıyla vakit geçirmekte ancak son zamanlarda toplumda görülen değişimlerin hiçbirinin anne karakterlerine yansıtılmadığı görülmektedir. Günümüzde kadınlar 
çalışma ve kamusal hayatta görünürdür ve bir ulaşım aracı da kullanmaktadır. Buna rağmen anneler aracılığıyla geleneksel rollerin üretimi sağlanmıştır. İncelenen yerli yapım çizgi filmlerin toplumsal cinsiyete dair kalıp yargıları içerdiği ve toplumsal cinsiyet eşitsizliğini yeniden ürettiği sonucuna ulaşılmıştır.

Öneriler: Erken çocukluk dönemi gelişimin en hızlı olduğu, kişilik gelişiminin büyük ölçüde tamamlandığı ve çocukların dünya ile ilgili görüşlerini oluşturdukları bir dönemdir. Bu dönem cinsiyet eşitliği ile ilgili alg1nın oluşturulması açısından önemli bir dönem olarak kabul edilmektedir. Çizgi film içeriklerini ve görsellerini oluşturan kişilerin bu konu ile ilgili daha bilinçli davranmaları gerekmektedir. Toplumsal cinsiyet eşitliği aç1sindan hem ana karakterler hem de yan karakterler eşit oranda temsil edilmelidir. Çizgi filmlerde yer verilen iş bölümü cinsiyetlere göre ayrılmış şekilde gerçekleştirilmemelidir. Özellikle ev ile ilgili işlere cinsiyet gözetmeksizin tüm karakterlerin eylemlerinde yer verilmelidir. Ev içi işler her bireyin cinsiyet ayrımına gitmeden yapabileceği işler olarak temsil edilmelidir. Davranış özelliklerinde de karakterler toplumsal cinsiyet kalıp yargılarına uygun davranışlar ve özellikler göstermemeli; bu kalıp yarg1ları içeren kişilik ve davranış özellikleri ile sınırlandırılmamalıdır.

Toplumsal cinsiyet inşası kültürel olarak biçimlendiğinden toplumsal cinsiyet eşitsizliği ile mücadele kültürel değişim yoluyla olabilir. Kültürü etkilemede önemli bir araç olan medya, toplumsal cinsiyet eşitsizliğini yeniden üretmek yerine özellikle çocuklara yönelik olarak toplumsal cinsiyet eşitliğini destekleyen çizgi film içerikleri üretmelidir.

Çizgi filmler sürekli değişmekte ve farklı çizgi filmler yayına girmektedir. Araştırmalarda hem yerli hem de yabanc yapım çizgi filmlerin toplumsal cinsiyet açısından incelenmesi, karşılaştırmalı çalışmaların yapılması önerilmektedir.

\section{Teşekkür}

İlgisini ve desteğini benden hiçbir zaman esirgemeyen ve bu çalışmanın ortaya çıkmasında önemli katkıları olan yüksek lisans tez danışmanım Prof. Dr. Aylin Görgün Baran'a teşekkürlerimi sunarım. 


\section{EXTENDED ABSTRACT \\ Gender (In)Equality in Turkish Cartoon Series \\ * \\ Ayşegül Deniz \\ Hacettepe University}

Gender is a concept that refers to social or cultural distinctions and roles associated with being male or female. This concept expresses the subjective dimension of gender-related to social structure and relationships beyond personality traits. The media is one of the means of socialization and plays an important role in determining the cultural and social structure of society and in changing social judgments for the positive or negative. The media has as much influence on children's learning of gender roles as their families and is considered one of the most important tools in reproducing gender inequality. Gender Schema Theory emphasizes that children receive important information about gender categories and gender roles from parents, teachers, and the media (Bem, 1983). Children start watching television at a very early age and the most-watched television programs by children are cartoons. Recently, both thematic children's channels and Turkish cartoon series have increased in Turkey. As of 2021, there are a total of 14 thematic children's channels broadcasting in encrypted and unencrypted in our country. TRT Çocuk broadcasts unencrypted while other children's channels broadcast encrypted. Cartoons also teach gendered concepts and experiences to children. In this context, it is important to investigate how these themes are implemented in cartoons from the point of view that gender roles are socially constructed.

This study aims to examine Turkish cartoon series broadcast on thematic children's channels in terms of gender equality. In this context, a total of 83 episodes of Biz İkimiz, Canım Kardeşim, Kral Şakir and Neşeli Dünyam were analyzed using the technique of content analysis, one of the qualitative research techniques. The characters of mothers, fathers, girls, and boys were examined in terms of gender equality in the categories of being in public spaces, activities of daily living and behavioral characteristics. Communication with children was analyzed as a separate category for the characters of mothers and fathers. 
In this study, it was found that mother characters spent less time in public spaces than father characters. The mothers focused on cooking, housework and baby care and represented the characteristics of emotional and domestic. Fathers were found to be more engaged in public spaces, perform daily activities such as repairing, driving, and going to work, related to science and technology, and were self-confident. The fathers have the characteristic of being like friends in their communication, but it was found that the mothers have more serious and instructive communication with their children. It was found that the girl and boy characters were similarly portrayed with the daily activities and behaviors of the mother and father characters. Girls were most associated with helping house works in daily life, while boys were associated with repairs. While girls value appearance and beauty, boys are portrayed as characters who are involved with science and technology. Gender stereotypes are shown to be reproduced in Turkish cartoons.

As a result, it can be said that the child characters and family members in the selected cartoons convey the values of urban and middle-class Turkish culture. In the cartoons, heterosexual relationships take place in an idealized form and the characters are portrayed with stereotypes within the gender binary. In this study, the main feature of the female type formed by the characters of the girl and the mother are that they are domestic and emotional characters who take place in private spaces and are interested in housework and cooking. The male type, formed by the characters of the boy and the father characters are in the public space, does repair work, drives a car, is self-confident, knowledgeable, entertaining, deals with science and technology, and leads actions. Girl characters are thought to perform similar actions with their mothers and boy characters with their fathers. The actions and behaviors of mothers and daughters, fathers and sons are almost identical. It can be interpreted that girls are portrayed as 'little women' and boys as 'little men'. These portrayals allow children to participate in the perpetuation of their gender roles by taking on these roles into adulthood. Fathers spend time with their children through their changing father roles, but none of the recent changes in society are reflected in the mother figures. Women are now visible at work and in public life and drive cars. Nevertheless, the traditional roles were created by 
mother characters. This situation has been interpreted as children reinforcing stereotypes about gender through cartoons. Because gender construction is culturally shaped, changes in gender inequality can be through cultural change. The media is an important tool in influencing culture and should produce cartoon content that supports gender equality, especially for children, instead of reproducing gender inequality. Further studies may be designed to compare findings of Turkish cartoons and foreign cartoons in terms of gender equity.

\section{Kaynakça / References}

Acar Savran, G. (2019). Beden emek tarih diyalektik bir feminizm için. Ankara: Dipnot Yayınları.

Adaçay, F. R. (2018). Toplumsal cinsiyetin yaratılması ve sürdürülmesinde temel kurumların rolü. Uluslararası İnsan Çalışmaları Dergisi, 1(2), 246265.

Ahmed, S. and Wahab, J. A. (2014). Animation and socialization process: Gender role portrayal on cartoon network. Asian Social Science, 10(3), 4453.

Akkuş, S. Y., Yılmazer, Y., Şahinöz, A. ve Sucaklı, İ. A. (2015). 3-60 ay arası çocukların televizyon izleme alışkanlıklarının incelenmesi. Hacettepe Üniversitesi Sağlık Bilimleri Fakültesi Dergisi, 1(2), 351-360.

Aley, M. and Hahn, L. (2020). The powerful male hero: A content analysis of gender representation in posters for children's animated movies. Sex Roles, 83(7-8), 499-509.

Alkan, A. (2000). Özel alan-kamusal alan ayrımının feminist eleştirisi çerçevesinde kentsel mekan. Kültür ve Illetişim, 3(1), 71-95.

Aral, N. ve Doğan Keskin, A. (2018). Ebeveyn bakış açısıyla 0-6 yaş döneminde teknolojik alet kullanımınin incelenmesi. Addicta: The Turkish Journal on Addiction, 5(2), 317-348.

Atay, M. ve Çelebi Öncü, E. (2020). Elektronik bakıc1; televizyon. S. İçin Akçalı (Ed.). Çocuk ve medya (s.69-82) içinde. Ankara: Nobel Yayıncllık.

Atkinson, R. L., Atkinson, R. C. and Hilgard, E. R. (2012). Psikolojiye giriş. İstanbul: Arkadaş Yayınları.

Aubrey, J. S. and Harrison, K. (2004). The gender-role content of children's favorite television programs and its links to their gender-related perceptions. Media Psychology, 6(2), 111-146. 
Bağçeli Kahraman, P. ve Özdemir, H. (2019). Resimli çocuk kitaplarının toplumsal cinsiyet rolleri açısından incelenmesi. Akdeniz Eğitim Araştırmalarn Dergisi, 13(27), 64-85.

Bahar, H. İ. (2015). Sosyoloji. İstanbul: Hayat Yayınları.

Barner, M. R. (1999). Sex-role stereotyping in FCC-mandated children's educational television. Journal of Broadcasting \& Electronic Media, 43, 551564.

Barutçu, A. ve Hıdır, N. (2016). Türkiye'de babalığın değişen rolleri: (Pro)feminist babalar. Fe Dergi, 8(2), 27-45.

Baştürk Akca, E. ve Ergül, S. (2015). Kitle iletişim çalışmaları alanında toplumsal cinsiyet çalışmalarının gelişimi; temel yaklaşımlar ve çalışmalar üzerinden bir çerçeve çizme çabası. Ş. Yavuz (Der.). Toplumsal cinsiyet ve medya temsilleri (s.17-44) içinde. İstanbul: Heyamola Yayınları.

Bem, S. L. (1983). Gender schema theory and its implications for child development: raising gender-aschematic children in a gender-schematic society. Signs, 8(4), 598-616.

Berktay, F. (2011). Toplumsal cinsiyet sosyolojisine başlangıç. Y. Ecevit ve Karkıner, N. (Ed.). Toplumsal cinsiyet sosyolojisi (s.2-31) içinde. Eskişehir: Anadolu Üniversitesi Yayınları.

Bilton, T., Bonnett, K., Jones, P., Lawson, T. and Skinner, D. S. M., ve Webster, A. (2008). Sosyoloji. İstanbul: Siyasal Kitabevi.

Bora, A. (2011). Toplumsal cinsiyete dayah ayrımcılık. Ayrımcılık: Çok boyutlu yaklaşımlar. İstanbul Bilgi Üniversitesi Sosyoloji ve Eğitim Çalışmaları Birimi.

Bora, A. ve Üstün, İ. (2008). Sıcak aile ortamı. İstanbul: TESEV Yayınları.

Browne, K. (2014). Sosyolojizye giriş. İstanbul: Say Yayınları.

Calvert S. L., Kotler, J. A., Zehnder, S. M. and Shockey, E. M. (2003). Gender stereotyping in children's reports about educational and informational television programs. Media Psychology, 5, 139-162.

Calvert, S. (1999). Children's journeys through the information age. Boston: McGraw-Hill.

Cesur, S. ve Paker, O. (2007). Televizyon ve çocuk: Çocukların TV programlarına ilişkin tercihleri. Elektronik Sosyal Bilimler Dergisi, 6(19), 106-125.

Chodorow, N. (1978). The reproduction of mothering, psychoanalysis and the sociology of gender. London: University of California Press. 
Chu, D. and McIntyre, B. T. (1995). Sex role stereotypes on children's TV in Asia a content analysis of gender role portrayals in children's cartoons in Hong Kong. Communication Research Reports, 12(2), 206-219.

Coyne, S. M., Linder, J. R., Rasmussen, E. E., Nelson, D. A. and Birkbeck, V. (2016). Pretty as a princess: Longitudinal effects of engagement with Disney princesses on gender stereotypes, body esteem, and prosocial behavior in children. Child Development, 87, 1909-1925.

Coyne, S., Linder, J., Rasmussen, E., Nelson, D. and Collier, K. (2014). It's a bird! It's a plane! It's a gender stereotype!: Longitudinal associations between superhero viewing and gender stereotyped play. Sex Roles, 70, 416-430.

Çabuklu, Y. (2007). Toplumsal kurgular ve cinsiyetçilik. İstanbul: Everest Yayınlar1.

Donovan, J. (2020). Feminist teori. (Çev. A. Bora, M., Ağduk Gevrek ve F. Sayılan). İstanbul: İletişim Yayınları.

Duman, A. E. ve Koçtürk, N. (2021). Yerli yapım bir çizgi filmin toplumsal cinsiyet rolleri açısından incelenmesi: Pırıl. Anemon Muş Alparslan Üniversitesi Sosyal Bilimler Dergisi, 9(Toplum \& Siyaset), 83-92.

Dundes, L. (2001). Disney's modern heroine Pocahontas: Revealing age-old gender stereotypes and role discontinuity under a façade of liberation. Social Science Journal, 38, 353-365.

Edwin M., Afi Roshezry A. B., Ira M. I., Geetha V., Norazleen, M. N., Lim, E. A. Taufik A. L. and Yann, N. K. (2012). A comparative study of gender roles in animated films. Global Journal Of Human Social Science, 12(5), 73-78.

Eick, K. (1998). Gender stereotypes in children's television cartoons. Adolescence, 37(253), 7.

England, D. E., Descartes, L. and Collier Meek, M. A. (2011). Gender role portrayal and the Disney princesses. Sex roles, 64(7-8), 555-567.

Fischer, S. (2010). Powerful or pretty: A content analysis of gender images in children's animated films. (Yüksek lisans tezi). Erişim adresi: https://etd.auburn.edu/bitstream/handle/10415/2065/ThesisSabrinaFischer.pdf?sequence $=2$, Erişim tarihi.10.06.2021.

Giddens, A. (2012). Sosyoloji. (Çev. C. Güzel). İstanbul: Kırmızı Yayınları.

Giddens, A. (2020). Sosyoloji kısa fakat eleştirel bir giriş. (Çev. Ü. Y. Battal). Ankara: Siyasal Kitabevi. 
Giroux, H. A. (1983). Ideology and agency in the process of schooling. Journal of Education,165(1), 12-34.

González, M. P. L., Paniagua, Á. I., Thornborrow, T. and Jordán, O. C. (2020). Associations between media representations of physical, personality, and social attributes by gender: A content analysis of children's animated film characters. International Journal of Communication, 14(2020), 6026-6048.

Gölgelioğlu, Ö. (2011). Siyaset ve katılım. Y. Ecevit ve N. Karkıner (Ed.). Toplumsal cinsiyet sosyolojisi (s.64- 83) içinde. Eskişehir: Anadolu Üniversitesi Yayınları.

Görgün Baran, A. (2012). Toplumsal cinsiyet. N. Güngör Ergan, B. Şahin Kütük, R. Coştur. (Ed.). Davranış bilimleri (s.410-438) içinde. Ankara: Siyasal Kitabevi.

Görgün Baran, A. Sarıtaş, C. ve Şahin Kütük, B. (2017). Medya'da kadına yönelik şiddet haberlerinin içerik ve sunum açısından analizi: Beyazgazete.com örneği. Sosyoloji Konferanslart: Prof. Dr. Fügen Berktay'a Armağan Özel Sayısı, 55, 107-132.

Karkıner, N. (2015). Toplumsal cinsiyet ve toplumsal cinsiyete farklı kuramsal yaklaşımlar. S. Yağan Güder. (Ed.). Cinsel eğitim ve toplumsal cinsiyet (s. 51-78) içinde. Ankara: Eğiten Kitap.

Götz, M., Hofmann, O., Brosius, H., Carter, C., Chan, K., Donald, S. ve diğ. (2008). Gender in children's television worldwide. Results from a media analysis in 24 countries. TelevIZIon, 21, 4-9.

Güler, N. (2014). İletişim, toplumsal cinsiyet ve ideoloji. Journal of Yaşar University, 9(34), 6023-6043.

Gümüşoğlu, F. (2008). Ders kitaplarında toplumsal cinsiyet. Toplum ve Demokrasi, 2(4), 39-50.

Günindi Ersöz, A. (2015). Özel alan / kamusal alan dikotomisi: Kadınlığın "doğası" ve kamusal alandan dışlanmışlı̆̆ı. Sosyoloji Araştırmaları Dergisi, 18(1), 80-102.

Gürsoy, Ö. (2012). Televizyon dizilerinde değişen aile değerleri. (Der.). N. Türkoğlu. Medya ve toplumsal dönüşüm seyirlik cümbüşler (s.191-318) içinde. İstanbul: Parşömen Yayıncılık.

Hentges, B. and Case, K. (2012). Gender representations on Disney Channel, Cartoon Network, and Nickelodeon Broadcasts in the United States. Journal of Children and Media, 7(3), 319-333. 
https://cartoonnetworkturkiye.fandom.com/tr/wiki/Cartoon_Network_Reytingleri, Erişim Tarihi: 08.08.2019.

https://fav10.net/forum/threads/9-eyl\%C3\%BCl-2019-pazartesi-reytingsonu\%C3\%A7lar\%C4\%B1.289691/, Erişim Tarihi: 10.09.2019.

https://www.gazeteduvar.com.tr/hayat/2017/10/26/reyting-listeleri-alt-ust-olacaktrt-cocuk-cekiliyor, Erişim Tarihi: 07.08.2019.

https://www.medyafaresi.com/ratingler/2017-07-31, Erişim Tarihi: 08.08.2019.

Işık, M. (Ed.), Erdem, A., Güllüoğlu, Ö. ve Akbaba, E. (2007). Televizyon ve çocuk. Konya: Eğitim Kitabevi Yayınları.

İçin Akçalı, S. (Ed.). (2020). Çocuk ve medya. Ankara: Nobel Yayıncılık.

İnal, K. (2020). Türkiye' de çocukluk nereye. S. İçin Akçalı. (Ed.) Çocuk ve medya (s.13-52) içinde. Ankara: Nobel Yayıncılık.

Jaggi, R. (2015). Deconstructing gender in cartoon programming on children's television channels in India-a textual analysis. IMS Manthan (The Journal of Innovations), 10(1), 123-130.

Kalaycı, N. (2015). Toplumsal cinsiyet eşitliği açısından bir çizgi film çözümlemesi. Eğitim ve Bilim, 40, 243-270.

Karkıner, N. (2015). Toplumsal cinsiyet ve toplumsal cinsiyete farklı kuramsal yaklaşımlar. S. Yağan Güder. (Ed.). Cinsel eğitim ve toplumsal cinsiyet (s.51-78) içinde. Ankara: Eğiten Kitap.

Keloğlu İşler, E. (2014). Kültürel ekme kuramı bağlamında Türkiye üretimi çizgi filmler ve çocuk bilincinin inşası. İletişim ve Diplomasi Dergisi, 2, 65-80.

Kidenda, M. C. A. (2018). Impact of animated cartoons on children aged seven to eleven years in Nairobi, Kenya. American Journal of Education and Practice, 3(1), 10-32.

Knobloch, S., Callison, C., Chen, L., Fritzsche, A. and Zillmann, D. (2005). Children's sex-stereotyped self-socialization through selective exposure to entertainment: Cross-cultural experiments in Germany, China, and the United States. Journal of Communication, 55(1), 122-138.

Koeman, J., Peeters, A. L. and D'Haenens, L. (2007). Diversity monitor 2005: Diversity as a quality aspect of television in the Netherlands. Communications, 32(1), 97-121.

Kurdoğlu, A. (2011). Kent yaşamı. Y. Ecevit ve Karkıner, N. (Ed.). Toplumsal cinsiyet sosyolojisi (s.106-129) içinde. Eskişehir: Anadolu Üniversitesi Yayınları. 
Kuzucu, Y. (2011). Değişen babalık rolü ve çocuk gelişimine etkisi. Türk Psikolojik Danışma ve Rehberlik Dergisi, 4(35), 79-89.

Laughey, D. (2010). Medya çalışmaları. İstanbul: Kalkedon Yayınları.

Lindsey, L. L. (2011). Gender roles- a sociological perspective. Boston: Prentice Hall.

Martin, C. L., Ruble, D. N. and Szkrybalo, J. (2002). Cognitive theories of early gender development. Psychological Bulletin, 128, 903-933.

Miles, M. B. and Huberman, A. M. (2019). Genişletilmiş bir kaynak kitap: Nitel veri analizi. S. Akbaba Altun ve A. Ersoy. (Çev. Ed.). (2. Baskıdan Çeviri, 3. Baskı). Ankara: Pegem Akademi.

Muratoğlu Pehlivan, B. (2019). Toplumsal cinsiyet rolleri açısından Türk çizgi filmlerinde anne ve baba temsili üzerine bir çalışma. Medya ve Kültürel Çalışmalar Dergisi, 1(2), 15-27.

Oakley, A. (2016). Sex, gender and society. New York: Routledge.

Ogletree, S. M., Martinez, C. N., Turner T., R. and Mason, B. (2004). Pok'emon: Exploring the role of gender. Sex Roles, 50, 851-859.

Oğuz Rollas, B. (2017). 0-6 yaş resimli çocuk hikaye kitaplarında toplumsal cinsiyet inşası. (Yayımlanmamış yüksek lisans tezi). Yaşar Üniversitesi, Sosyal Bilimler Enstitüsü, Sanat ve Tasarım Anasanat Dalı, İzmir.

Oruç, C., Tecim, E. ve Özyürek, H. (2011). Okul öncesi dönem çocuğunun kişilik gelişiminde rol modellik ve çizgi filmler. Ekev Akademi Dergisi, 15(48), 281-297.

Özen Uyar, B. ve Yılmaz Genç, M. M. (2017). Yerli yapım çizgi filmlerde sunulan toplumsal cinsiyet rolleri. Ö. Demirel ve S. Dinçer. (Ed.). Küreselleşen dünyada eğitim (s.679-712) içinde. Ankara: Pegem Akademi Kitabevi Yayınları.

Özgökbel Bilis, P. (2011). Çizgi filmlerde temsil edilen toplumsal değerler sistemi (Yayımlanmamış doktora tezi). Ege Üniversitesi, Sosyal Bilimler Enstitüsü, Radyo Televizyon Anabilim Dalı, İzmir.

Özsoy, M. ve Taşdelen, E. Ş. (2016). Pepee çizgi dizisinde toplumsal cinsiyet rollerinin üretimi. İletişim ve Kuram Araştırma Dergisi, 42, 252-265.

Öztürk, C. ve Karayağız, G. (2007). Okulöncesi dönemdeki çocukların televizyon izleme durumları ve bunu etkileyen incelenmesi. Milli Ĕ̆itim, 175, 116-128.

Rozario, A., Masilamani, V. and Arulchelvan, S. (2018). The case of the missing girls: Distribution of gender roles in Indian children's television programming. Journal of Children and Media, 12, 125 - 142. 
RTÜK (2016). RTÜK 2016-2020 stratejik plan özeti. https://www.rtuk.gov.tr/assets/Icerik/AltSiteler/rtuk-2016-2020-stratejik-plani-ozeti.pdf adresinden erişilmiştir. Erişim tarihi 19.02.2019.

Ruble, D. N., Martin, C. L. and Berenbaum, S. A. (2006). Gender development. ed. W. Damon \& R. Lerner (Ed.). Handbook of child psychology, vol. 3: Social, emotional, and personality development (s.858-932) içinde. New York: Wiley.

Rudy, R. M., Popova, L. and Linz, D. G. (2010). The context of current content analysis of gender roles: An introduction to a special issue. Sex Roles, $62,705-729$.

Sancar, S. (2020). Erkeklik: İmkânsız iktidar-ailede, piyasada ve sokakta erkekler. İstanbul: Metis Yayınları.

Saraç, H. (2018). Okul öncesi dönem çocuklarına yönelik çizgi filmlerde toplumsal cinsiyetin inşası: Niloya örneği. (Yayımlanmamış yüksek lisans tezi). İstanbul Üniversitesi, Sosyal Bilimler Enstitüsü, Kadın Çalışmaları Anabilim Dalı, İstanbul.

Sarıtaş, E. ve Şahin, Ü. (2018). Hayat bilgisi ders kitaplarında toplumsal cinsiyet rolleri üzerine bir inceleme. Mehmet Akif Ersoy Üniversitesi Ĕ̆itim Fakültesi Dergisi, 48, 463-477.

Sayıl, M. ve Yağmurlu, B. (2012). Türkiye'de ana babalık çalışmalarına bakış. M. Sayıl ve B. Yağmurlu (Der.). Ana babalık: Kuram ve araştırma (s.1518) içinde. İstanbul: Koç Üniversitesi Yayınları.

Sheikh, A. A. (2017). Stereotypical gender representations in Chhota Bheem: Kids' cartoon programme on Pogo Channel. Pakistan Journal of Women's Studies: Alam-e-Niswan, 24(2), 15-32.

Şen, B. (2020). Okul öncesi dönem çocukları tarafindan izlenen çizgi filmlerin toplumsal cinsiyet açısından incelenmesi. (Yayımlanmamış doktora tezi). Gazi Üniversitesi, Eğitim Bilimleri Enstitüsü, Okul Öncesi Öğretmenliği Bilim Dalı, Ankara.

Şirin, M. R., Oktay, N. ve Altun A. (2013). I. Türkiye çocuk ve medya stratejisi ve uygulama planı 2014-2018. İstanbul: Çocuk Vakfı Yayınları.

Tavşancıl, E. ve Aslan, A. E. (2001). Sözel, yazılı ve diğer materyaller için içerik analizi ve uygulama örnekleri. İstanbul: Epsilon Yayınevi.

Taylor, S. E., Peplau, L. A. ve Sears, D. O. (2015). Sosyal psikoloji. (çev.Ali Dönmez). Ankara: İmge Yayınevi.

Tezel Şahin, F. (2007). Sosyal değişim sürecinde değişen baba rolü. Uluslararası Asya ve Kuzey Afrika Çalışmaları Kongresi 38. ICANAS, Ankara. 
Thompson, T. L. and Zebrinos, E. (1995). Gender roles in animated cartoons: Has the picture changed in 20 years. Sex Roles, 32, 651-673.

Towbin, M. A., Haddock, S. A., Zimmerman, T. S., Lund, L. K. and Tanner, L. R. (2003). Images of gender, race, age, and sexual orientation in Disney feature-length animated films. Journal of Feminist Family Therapy, $15,19-44$.

Ünlü, A. S. (2017). Toplumsal cinsiyet rolleri bakımından TRT çocuk kanalında yayımlanan çizgi filmler (Yayımlanmamış yüksek lisans tezi). Erzincan Üniversitesi, Sosyal Bilimler Enstitüsü, Türkçe Eğitimi Bilim Dalı, Erzincan.

Wall, G. and Arnold, S. (2007). How involved is involved fathering? An exploration of the contemporary culture of fatherhood. Gender \& Society, 21(4), 508-527.

Walsh, A. and Leaper, C. (2020). A content analysis of gender representations in preschool children's television. Mass Communication and Society, 23(3), 331-355.

Ward, L. M. and Grower, P. (2020). Media and the development of gender role stereotypes. Annual Review of Developmental Psychology, 2, 177-199.

Wiserma, B. A. (2001). The gendered world of Disney: A content analysis of gender themes in full-length animated Disney feature films. Dissertation Abstracts International, 61, 4973.

Yağan Güder, S., Ay, A., Saray, F. ve Kılıç, İ. (2017). Okul öncesi dönem çocuklarının izledikleri çizgi filmlerin toplumsal cinsiyet kalıp yargıları açısından incelenmesi: Niloya örneği. Eğitimde Nitel Araştırmalar Dergisi, 5(2), 96-111.

Yazıcı, E., Yaman Baydar, İ. ve Kandır, A. (2019). Çizgi film ve çocuk: Ebeveyn görüşleri. Adnan Menderes Üniversitesi Ĕ̆gitim Fakültesi Ĕ̆gitim Bilimleri Dergisi, 10(1), 10-19.

Zaheen, B. and Khan, M. A. (2019). Children, gender and television: An analysis of heavy viewers' behaviour regarding gender-specific roles and characteristics. Global Regional Review, 4(2), 364-374.

Zaheen, B., Manzoor, S. and Safdar, A. (2020). TV cartoon Programs: An analysis of gender roles and characteristics. Pakistan Social Sciences Review, 4(2), 460-472.

Zastrow, C. and Kirst Ashman, K. K. (2014). İnsan davranışı ve sosyal çevre I. Ankara: Nika Yayınevi. 


\section{Kaynakça Bilgisi / Citation Information}

Deniz, A. (2021). Yerli Yapım çizgi filmlerde toplumsal cinsiyet eşit(siz)liği. OPUS-Uluslararası Toplum Araştırmaları Dergisi, 18(43), 6942-6979. DOI: 10.26466/opus. 910874. 